\title{
The Impact of Environmental Risk Factors on Delirium and Benefits of Noise and Light Modifications: A Scoping Review
}

Haleh Hashemighouchani, MD ${ }^{1,2}$; Julie Cupka, BS ${ }^{1,2}$; Jessica Lipori, BA ${ }^{1,2}$; Matthew M Ruppert, BS ${ }^{1,2}$;

Elizabeth Ingersent ${ }^{1,2}$; Tezcan Ozrazgat-Baslanti, $\mathrm{PhD}^{1,2}$; Parisa Rashidi, $\mathrm{PhD}^{2,3}$;Azra Bihorac, MD MS ${ }^{1 \text {, }}$

2

${ }^{1}$ Department of Medicine, University of Florida, Gainesville, FL, USA

${ }^{2}$ Precision and Intelligent Systems in Medicine (Prisma ${ }^{\mathrm{P}}$ ), University of Florida, Gainesville, FL, USA

${ }^{3}$ Department of Biomedical Engineering, University of Florida, Gainesville, FL, USA

Funding: A.B., T.O.B., and P.R. were supported by R01 GM110240 from the National Institute of General Medical Sciences. A.B. and T.O.B. were supported by Sepsis and Critical Illness Research Center Award P50 GM-111152 from the National Institute of General Medical Sciences. A.B. and M.R. were supported by Davis Foundation - University of Florida. P.R. was supported by the NSF CAREER 1750192 and NIH/NIBIB 1R21EB027344 grants. T.O.B. received a grant supported by the National Center for Advancing Translational Sciences of the National Institutes of Health under Award Number UL1TR001427 and received a grant from Gatorade Trust (127900), University of Florida.

Conflicts of Interest: The authors declare that they have no competing interests.

Correspondence can be sent to: Azra Bihorac, MD, MS, FASN, FCCM, Department of Medicine, Division of Nephrology, Hypertension, \& Renal Transplantation, 1600 SW Archer Road, PO Box 100224, Communicore Building, Room CG-98, Gainesville, FL 32610-0224. Office Phone (352) 2739009; Fax: (352) 392-5465; E-mail: abihorac@ufl.edu 
medRxiv preprint doi: https://doi.org/10.1101/2020.05.20.20108373; this version posted May 28, 2020. The copyright holder for this preprint (which was not certified by peer review) is the author/funder, who has granted medRxiv a license to display the preprint in perpetuity.

It is made available under a CC-BY-NC 4.0 International license .

\begin{abstract}
Purpose: To explore existing literature on the association between environmental risk factors with delirium and to investigate the effectiveness of environmental modifications on prevention or management of delirium.
\end{abstract}

Materials and Methods: This is a scoping review of peer-reviewed studies in Pubmed and the reference lists of reviewed articles. Observational studies reporting the effect of noise, light, and circadian rhythm on delirium and interventional studies assessing delirium in modified environments were reviewed.

Results: Thirty eight studies were included, of which, 21 evaluated impact of environment on delirium, and 16 studied the interventions. Interventions targeted reducing noise exposure, improving light exposure to follow circadian rhythm, and promoting sleep. Mixed findings of the reviewed studies yielded to inconclusive results; however quiet-time protocols, earplugs, and bright light therapy might benefit prevention, or management of delirium.

Results: Thirty seven studies were included, 21 of which evaluated the impact of environment on delirium and 16 studied possible solutions to mitigate those impacts. Mixed findings of the reviewed studies yielded inconclusive results; a clearly delineated association between high noise levels, abnormal amounts of light exposure, and sleep disruption with delirium could not be established. Interventions targeted reducing noise exposure, improving day-time and mitigating night-time light exposure to follow circadian rhythm, and promoting sleep. The overall evidence supporting effectiveness of environmental interventions was also of a low confidence; however, quiet-time protocols, earplugs, and bright light therapy showed a benefit for prevention or management of delirium.

Conclusion: Environmental modifications are non-invasive, risk-free, and low-cost strategies that may be beneficial in preventing and managing delirium, especially when used as part of a multi-component plan. However, given the limited evidence-based conclusions, further high-quality and larger studies focusing on environmental modifications and delirium outcomes are strongly recommended.

Key Words: delirium, environmental intervention, noise, light, circadian, scoping review 
medRxiv preprint doi: https://doi.org/10.1101/2020.05.20.20108373; this version posted May 28, 2020. The copyright holder for this preprint (which was not certified by peer review) is the author/funder, who has granted medRxiv a license to display the preprint in perpetuity.

It is made available under a CC-BY-NC 4.0 International license .

\section{INTRODUCTION}

Delirium is a multifactorial, acute, state of confusion characterized by disturbance of consciousness and cognition; it is particularly common in the intensive care unit (ICU) with incidence ranging from 19 to $87 \%$ with especially higher rates in mechanically ventilated patients ${ }^{1-3}$. ICU delirium is associated with adverse outcomes, including prolonged mechanical ventilation, increased risk of longterm cognitive dysfunction, prolonged ICU and hospital stays, higher cost of care, and increased mortality 4-7. While the pathophysiology of delirium is poorly understood, there are multiple factors associated with an increased risk for developing delirium, including age, level of education, pre-existing conditions such as hypertension, neurological or psychological disorders, illness severity, Acute Physiology and Chronic Health Evaluation II (APACHE II) score, sensory impairment, and use of analgesics, sedatives, and polypharmacy ${ }^{8-12}$. In addition, the ICU environment may contribute as a potentially modifiable risk factor for developing delirium. Decreased natural daylight, night-time light exposure, excessive noise, immobilization, use of physical restraints, and isolation are potential delirium risk factors in ICU ${ }^{13-15}$.

ICU noise levels are above internationally recommended levels by the World Health Organization's (WHO) recommendations, which suggest 30 A-weighted decibels (dBA) for background noise, a maximum of $35 \mathrm{dBA}$ for treatment and observation areas, and a maximum of $40 \mathrm{dBA}$ at night in a hospital setting ${ }^{16-18}$. Patients interviewed post-ICU discharge report noise as an overall stressor and contributor to loss of sleep ${ }^{19,20}$. Another common environmental disturbance for ICUs is non-cycling light sources. Disruptions in normal amounts of blue light $(460-480 \mathrm{~nm})$ hitting the retina affect neurological processes responsible for melatonin release ${ }^{15}$. Constant delivery of these wavelengths may cause abnormal suppression of melatonin release, thus potentially, altering circadian cycles ${ }^{15}$. Although the nature of the ICU environment does not lend itself to quietude, it is feasible to employ noise-reducing and light modifications that synchronize circadian rhythm, facilitating recovery.

Prevalence of delirium-associated adverse effects and the multitude of risk factors in the ICU make delirium prevention and management essential. Current strategies include pharmacological, nonpharmacological, and multi-component interventions geared towards decreasing delirium incidence and 
medRxiv preprint doi: https://doi.org/10.1101/2020.05.20.20108373; this version posted May 28, 2020. The copyright holder for this preprint (which was not certified by peer review) is the author/funder, who has granted medRxiv a license to display the preprint in perpetuity.

It is made available under a CC-BY-NC 4.0 International license .

duration. Pharmacological interventions focus on haloperidol and dexmedetomidine, with limited research into ramelteon, melatonin, and ziprasidone ${ }^{21-24}$. The largest clinical trial to date on haloperidol or ziprasidone in delirious patients failed to show significant clinical benefit ${ }^{23}$, and current literature does not support use of anti-psychotic agents, benzodiazepines, or melatonin in delirium management ${ }^{21,25}$. Given the lack of evidence supporting pharmacological measures, research into efficacy of nonpharmacological techniques such as noise reduction or dynamic lighting is crucial. Implementing effective delirium management strategies shows promise in decreasing morbidity, mortality, length of stay, and resource burden in the ICU ${ }^{2}$. The purpose of this scoping review is to map existing literature identifying modifiable environmental risk factors for delirium, and assess the role of non-pharmacological noise, light, and circadian rhythm interventions for delirium prevention and management.

\section{MATERIALS AND METHODS}

This review was conducted according to methods of Arksey and O'Malley ${ }^{26}$ and Levac et al. ${ }^{27}$, and reported following the Preferred Reporting Items for Systematic Reviews and Meta-Analyses (PRISMA) Extension for Scoping Reviews ${ }^{28}$ (Supplementary Table 1). The aim of this review is to examine the extent and nature of available literature, and highlight areas requiring further inquiry regarding these questions: "How do environmental noise, light, and disrupted circadian rhythms affect delirium?" and "How do existing environmental interventions help prevent or manage delirium?"

\section{Search Strategy and data charting}

Studies were identified by searching Pubmed for articles relating to our questions. Search results were restricted to the English language and peer-reviewed studies, with no restriction on year of publication. Search queries were generated using the following combination of keywords: ["delirium" AND “noise OR sound OR light OR circadian"]. The search was applied with no field tags to maximize results.

After compiling research results and removing duplicates, two authors screened titles and abstracts to retrieve articles for eligibility. Articles on pediatric populations, animal subjects, case reports, 
medRxiv preprint doi: https://doi.org/10.1101/2020.05.20.20108373; this version posted May 28, 2020. The copyright holder for this preprint (which was not certified by peer review) is the author/funder, who has granted medRxiv a license to display the preprint in perpetuity.

It is made available under a CC-BY-NC 4.0 International license .

or if the full-text was unavailable were excluded. Additional studies were identified through handsearches and searching the reference list of reviewed articles. Three authors reviewed the full text of eligible articles and extracted data using a pre-designed worksheet reviewed and tested by the team before data charting (Supplementary Table 2). Elements of the data charting worksheet included study design, setting, sample size, aim, detailed methodology, characteristics of intervention and control groups, measured outcomes, diagnostic tools, main conclusions, and study strengths and limitations. Any disagreements were resolved by thoroughly discussing any points of concern.

We included observational studies analyzing association between noise levels, light exposure, or disrupted circadian rhythm with delirium, and interventional studies assessing effectiveness of modified noise or light exposure or improved circadian rhythm on delirium. Articles were excluded if environmental intervention was an element of a multi-component non-pharmacological bundle, not the main focus. In initial full text review and data charting, we reviewed all interventional articles reporting results on delirium or environmental risk factors of delirium, including noise or light levels, and quality/quantity of sleep. We acknowledge these outcomes are modifiable risk factors linked to delirium prevention or management; however, to better map the existing literature related to our research question, we excluded articles without results linked to delirium. These articles are in Supplementary Table 3.

\section{RESULTS}

\section{Literature search results \& outcome}

The electronic database search retrieved 457 articles, which were screened by title and abstract, resulting in 166 studies for full-text review. Hand-search and searching reference lists added 28 additional articles. During full-text review of these 194 articles, 157 were excluded. In total 37 studies were included: 21 assessed association between environmental risk factors and delirium ${ }^{13,19,20,29-46}$, and 16 reported on delirium after an environmental intervention ${ }^{7,14,15,18,47-58}$ (Figure 1). 


\section{Figure 1. PRISMA Record Screening Flow chart}
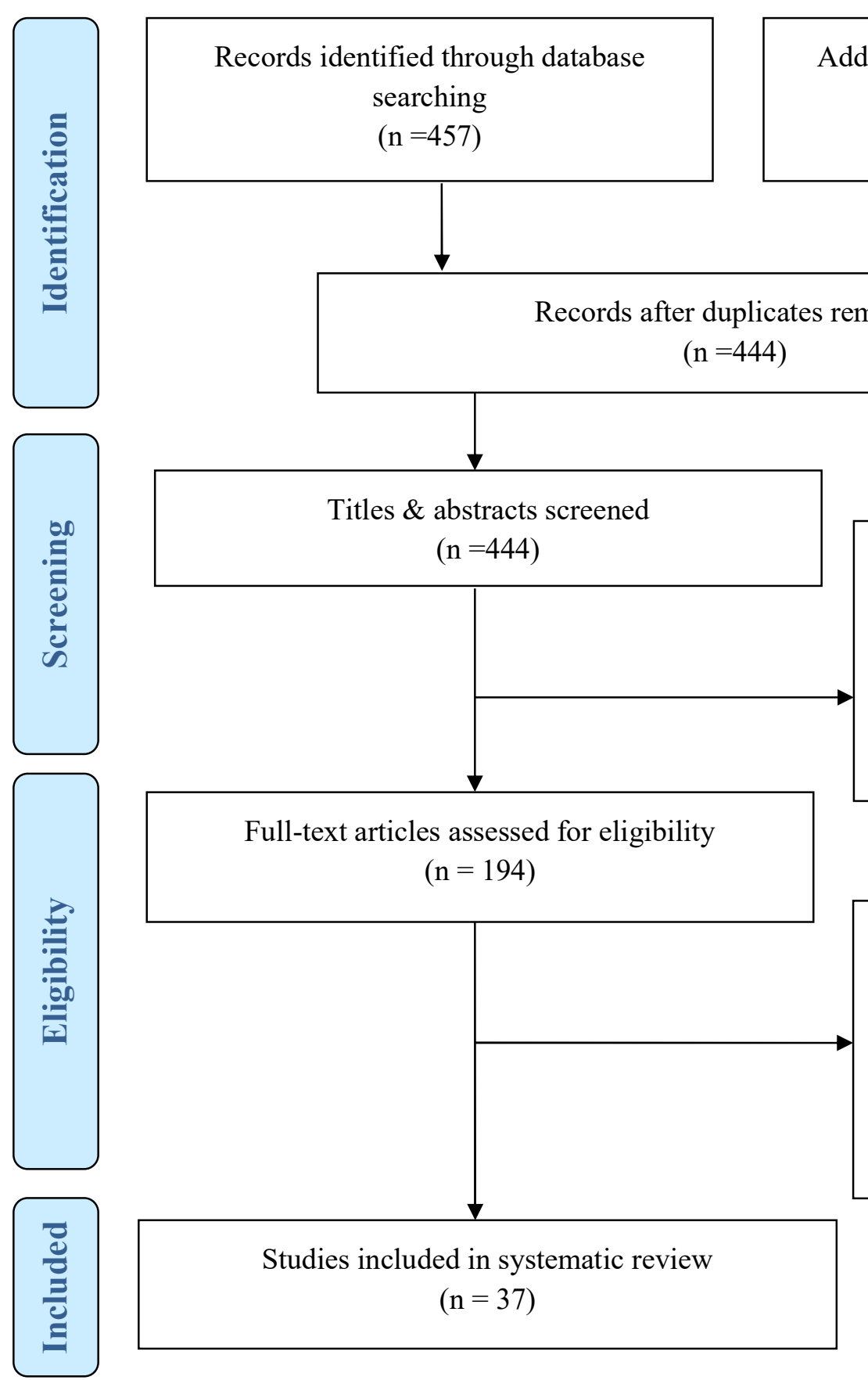

Records excluded $(\mathrm{n}=250)$

Not relevant $(\mathrm{n}=215)$

Animal $(\mathrm{n}=9)$

Pediatric $(n=12)$

Case Study $(\mathrm{n}=5)$

Abstract Only ( $\mathrm{n}=9)$

Full text articles excluded $(\mathrm{n}=157)$

Not meeting inclusion criteria $(\mathrm{n}=104)$

Review article $(\mathrm{n}=44)$

Commentary article $(\mathrm{n}=6)$

Study protocol $(\mathrm{n}=3)$

\section{Characteristics of the reviewed articles}

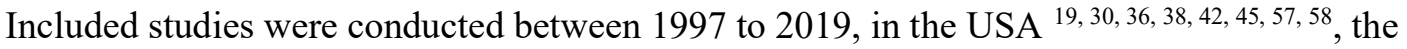
Netherlands ${ }^{14,31,47,49,50}$, Japan ${ }^{37,40,51,52}$, France ${ }^{32,35,56}$, Belgium ${ }^{13,48}$, Denmark ${ }^{15,33}$, Italy ${ }^{41,46}$, Sweden ${ }^{18,20}$, Canada ${ }^{34}$, China ${ }^{44}$, India ${ }^{39}$, Israel ${ }^{29}$, Singapore ${ }^{54}$, South Korea ${ }^{53}$, Thailand ${ }^{55}$, Turkey ${ }^{43}$, and UK ${ }^{7}$ 
medRxiv preprint doi: https://doi.org/10.1101/2020.05.20.20108373; this version posted May 28, 2020. The copyright holder for this preprint (which was not certified by peer review) is the author/funder, who has granted medRxiv a license to display the preprint in perpetuity.

It is made available under a CC-BY-NC 4.0 International license .

Thirty-one studies were conducted among critically ill patients while five reviewed general hospital populations $29,34,40,43,53$, and one a geriatric monitoring unit for acute delirium care ${ }^{54}$. Among the 37 reviewed articles, all observational association studies and 12 interventional studies reported delirium incidence, while 2 interventional studies measured delirium prevalence ${ }^{18,57}$. Delirium severity was assessed in three of the interventional studies ${ }^{47,53,54}$. Three articles also reviewed delirium duration ${ }^{7,47,50}$. Most studies assessed delirium using Confusion Assessment Method for the ICU (CAM-ICU) ${ }^{7}$, 15, 18, 19, 33, 35, 36, 38, 39, 41, 44-47, 50, 55-58; other identification methods included validated Dutch CAM-ICU ${ }^{31}$, Confusion Assessment Method (CAM) ${ }^{40,49,54}$, Intensive Care Delirium Screening Checklist (ICDSC) ${ }^{14,}$ ${ }^{32,42}$, Neelon and Champagne Confusion Scale (NEECHAM) ${ }^{13,48}$, non-validated ${ }^{51}$ and validated ${ }^{52}$ Japanese NEECHAM, Delirium Observation Screening Scale (DOSS) ${ }^{49}$, behavioral observations based on the Diagnostic and Statistical Manual of Mental Disorders, $3^{\text {rd }}$ edition (DSM-III) ${ }^{34}, 3^{\text {rd }}$ edition-revised (DSM-III-R) ${ }^{37}$, and $4^{\text {th }}$ Edition (DSM-IV) ${ }^{20,40,43}$, and behavioral observations based on International Classification of Diseases, $9^{\text {th }}$ Revision, Clinical Modification (ICD-9-CM) criteria ${ }^{29}$. One study used both retrospective chart review and site-specific pre-specified criteria based on new and rapid onset of disturbed consciousness and/or perceptual disturbances ${ }^{30}$. Studies assessed delirium severity by nonvalidated Delirium Severity Index (DSI) ${ }^{47}$, Delirium Rating Scale (DRS) ${ }^{53}$, Delirium Rating ScaleRevised-98 (DRS-R-98) ${ }^{54}$, and Memorial Delirium Assessment Scale (MDAS) ${ }^{53}$. Specific study details including study design, setting, sample size, method details, outcomes, and a brief description of findings with statistics are summarized in Table 1 for observational studies reporting on environmental risk factors, and Table 2 for environmental intervention studies.

\section{Effect of environmental risk factors on delirium}

Of the 21 observational studies, two analyzed for association between delirium and noise ${ }^{19,20}$, five for light factors and delirium ${ }^{13,29-32}, 12$ for sleep and delirium ${ }^{33-44}$, and two evaluated multiple factors (noise, light, and/or sleep with delirium) ${ }^{45,46}$. Study population ranged in size from 7 to 6660 participants, and the vast majority of studies were done in an ICU (17 of 21 studies) ${ }^{13,19,30-33,35-39,41,42,44-}$ 
medRxiv preprint doi: https://doi.org/10.1101/2020.05.20.20108373; this version posted May 28, 2020. The copyright holder for this preprint (which was not certified by peer review) is the author/funder, who has granted medRxiv a license to display the preprint in perpetuity. It is made available under a CC-BY-NC 4.0 International license.

46. The remaining four studies did not specify a ward and were performed in a general hospital setting ${ }^{29}$ $34,40,43$. Study details and reported statistical results are in Table 1.

\section{Noise}

Although ICU noise is a suggested predictor for delirium development, two of the three investigating studies found no significant association between ICU noise levels and delirium development 19, 20. One study assessed A-weighted sound levels with subjective patient reports on ICU noise ${ }^{20}$. They found no correlation between A-weighted equivalent continuous (LAeq) or maximum (LAmax) noise pressure levels and delirium, while patients' responses about ICU sounds spread evenly over a spectrum from scary to non-disturbing ${ }^{20}$. In comparison, Knauert et al. ${ }^{19}$ evaluated equivalent continuous sound pressure level (Leq) and peak sound occurrences for both A-weighted and C-weighted measurements, finding no correlation with delirium development. There are no industry-standard recommendations for C-weighted levels, but LAeq and LAmax values from both studies were higher than recommended by the WHO ${ }^{17,19,20}$. In contrast, a study by Davoudi et al. ${ }^{45}$ found average night-time sound pressure levels were significantly higher for patients with delirium ${ }^{45}$. However, they did not provide exact decibel measurements to compare with recommended WHO levels, likely because they were reporting preliminary findings for a larger cohort study unpublished at the time of this review ${ }^{45}$.

\section{Light}

Abnormal lighting cycles are another suggested contributor to delirium ${ }^{59}$. Seven of the reviewed studies considered exposure to natural sunlight and any statistical relationships with delirium ${ }^{13,29-32,45,46}$. There were two approaches to analysis: effects of windows on delirium incidence ${ }^{13,30,32,45,46}$ and association with admission season ${ }^{45,46}$. Findings were mixed across the studies, suggesting no easily provable relationship between natural light exposure and delirium occurrence. Two window and one seasonal study found no statistical association between delirium and windows or season of admission/duration of preadmission sunlight exposure, respectively ${ }^{30-32}$. Kohn et al. ${ }^{30}$ compared windowed versus non-windowed rooms in the medical ICU, and natural versus industrial window views in the surgical ICU. ${ }^{30}$. They also investigated impact of half-sized versus full-sized windows, finding no 
medRxiv preprint doi: https://doi.org/10.1101/2020.05.20.20108373; this version posted May 28, 2020. The copyright holder for this preprint (which was not certified by peer review) is the author/funder, who has granted medRxiv a license to display the preprint in perpetuity.

It is made available under a CC-BY-NC 4.0 International license .

association between delirium incidence and any of these factors ${ }^{30}$. Similarly, Smonig et al. found no difference in delirium incidence between patients admitted to windowed versus non-windowed rooms while proving windowed rooms retained natural circadian light variations and non-windowed rooms did not ${ }^{32}$. In the seasonal study, Simons et al. investigated effect of admission season with delirium and found no correlation ${ }^{31}$. A simultaneous assessment found no correlation between preadmission cumulative sunlight exposure and delirium incidence for three photoperiods (7, 28, and 60 days prehospital admission) ${ }^{31}$.

In comparison to studies showing no association between natural sunlight exposure and delirium occurrence, three window studies and one seasonal study found a significant correlation ${ }^{13,29,45,46}$. In the window studies, Simeone et al. ${ }^{46}$ associated lack of natural sunlight with delirium while Van Rompaey et al. ${ }^{13}$ found absence of visible daylight led to higher risk of delirium. Davoudi et al. ${ }^{45}$ examined pervasive sensing of ICU patients, finding measured light intensity in windowed rooms was significantly different between patients with and without delirium ${ }^{45}$. Additionally, a study on seasonal impact on delirium diagnosis by Balan et al. found a higher incidence of delirium among patients admitted in winter compared to summer ${ }^{29}$.

\section{Sleep}

Disrupted sleep-wake cycles are associated with altered mental state in hospitalized patients, and are connected with delirium ${ }^{60}$. In this review, 14 studies ${ }^{19,33-37,39-46}$ assessed sleep and delirium with two main methodologies: objective measurements of physiological sleep phases and subjective reports by staff or patient. Five studies objectively measured sleep quality using overnight polysomnography (PSG) or a Zeo wireless sleep monitor ${ }^{19,33,35,41,42}$, while eight assessed staff reports of behavioral observations and/or self-reports by patients ${ }^{33,34,36,37,40,44-46}$. One study compared both methods [33], and two did not specify their method of measurement, only stating that they evaluated the relationship between sleep deprivation and delirium ${ }^{39,43}$.

Similar to the articles on natural light exposure, association studies for sleep and delirium have mixed findings, but lean towards disrupted sleep being a delirium predictor. Six of 14 studies found no 
medRxiv preprint doi: https://doi.org/10.1101/2020.05.20.20108373; this version posted May 28, 2020. The copyright holder for this preprint (which was not certified by peer review) is the author/funder, who has granted medRxiv a license to display the preprint in perpetuity.

It is made available under a CC-BY-NC 4.0 International license .

relationship between sleep and delirium: two PSG studies ${ }^{19,33}$, three using subjective measures ${ }^{33}$, and one with unspecified method ${ }^{36,39,45}$. One study found no difference in rate of delirium between patients with typical and atypical sleep on PSG ${ }^{38}$, while another by Boesen et al. also found no difference in atypical PSG results between patients who did or did not develop delirium ${ }^{33}$. They compared PSG results with clinical behavioral observations and were only able to ascertain that the more pathological the patient and electroencephalogram findings, the less association with observed sleep ${ }^{33}$. A study using the Richards-Campbell Sleep Questionnaire (RCSQ) found no significant correlation between perceived sleep quality and delirium, nor any significant relationship when asking how disruptive noise was to sleep ${ }^{36}$. The study by Davoudi et al. ${ }^{45}$ used the Freedman Sleep Questionnaire and found no correlation between overall sleep quality and delirium, although they noted patients with delirium were more likely to have difficulty falling asleep and find night-time lighting disruptive ${ }^{45}$. The last study did not detail their methodology, but found delirium was not significantly related to sleep deprivation ${ }^{39}$.

Of nine studies showing statistical correlation between sleep and delirium, three used electronic sleep monitoring ${ }^{35,41,42}$, five subjective survey measures $34,40,44,46,61$ and one did not specify methodology ${ }^{43}$. One study found atypical sleep on PSG was significantly tied to increased delirium, while another PSG study found delirium was associated with severe REM reduction ${ }^{35,41}$. A third study used a novel sleep monitoring device and found a relationship between lack of rapid eye movement (REM) sleep and delirium ${ }^{42}$. Their results must be taken in the context of the device being commercially unavailable (Zeo wireless sleep monitor), and the authors not reporting statistical analyses. Among remaining positive correlational studies, two had patients self-report sleep satisfaction and quality and both saw significantly poorer responses when comparing patients who developed delirium with those who did not ${ }^{34,44}$. Two studies used nursing staff observing clinical behaviors and found sleep disturbances were positively linked to higher likelihood of developing delirium ${ }^{37,40}$. Two studies found an association between delirium incidence and sleep deprivation (methodology not specified) ${ }^{43}$, and between sleeping disorders and delirium development ${ }^{46}$.

\section{Effect of environmental interventions on delirium prevention and treatment}


medRxiv preprint doi: https://doi.org/10.1101/2020.05.20.20108373; this version posted May 28, 2020. The copyright holder for this preprint (which was not certified by peer review) is the author/funder, who has granted medRxiv a license to display the preprint in perpetuity.

It is made available under a CC-BY-NC 4.0 International license.

Sixteen studies evaluated effects of a modified environment on delirium prevention or management ${ }^{7,14,15,18,47-58}$ (Table 2). Half were randomized control trials (RCT) ${ }^{18,48,50-53,55,56}$, while half used different study designs including: before-after ${ }^{7,14,47,58}$, retrospective cohort $^{15,49}$, and prospective cohort ${ }^{54,57}$. Sample sizes varied from 11 to 748 . Interventions focused on controlling environmental risk factors, including noise and light exposure, disrupted circadian rhythm, and sleep (Figure 2). We categorized these interventions into four modification types: architectural design ${ }^{18,47}$, environmental noise ${ }^{14,48}$, environmental light ${ }^{15,49-56}$, and environmental modification bundles with noise and light components $^{7,56-58}$. A summary of environmental interventions on delirium and reported statistical results are presented in Table 3.

Figure2. Environmental Risk Factors for Delirium, and the Mitigation Strategies

Environmental Risk Factors

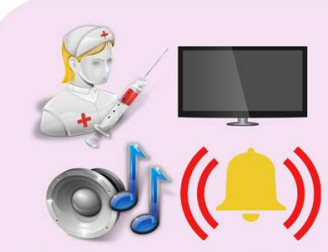

Environmental Noise
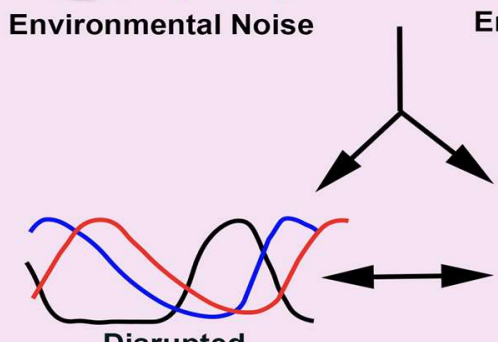

adian Rhythm
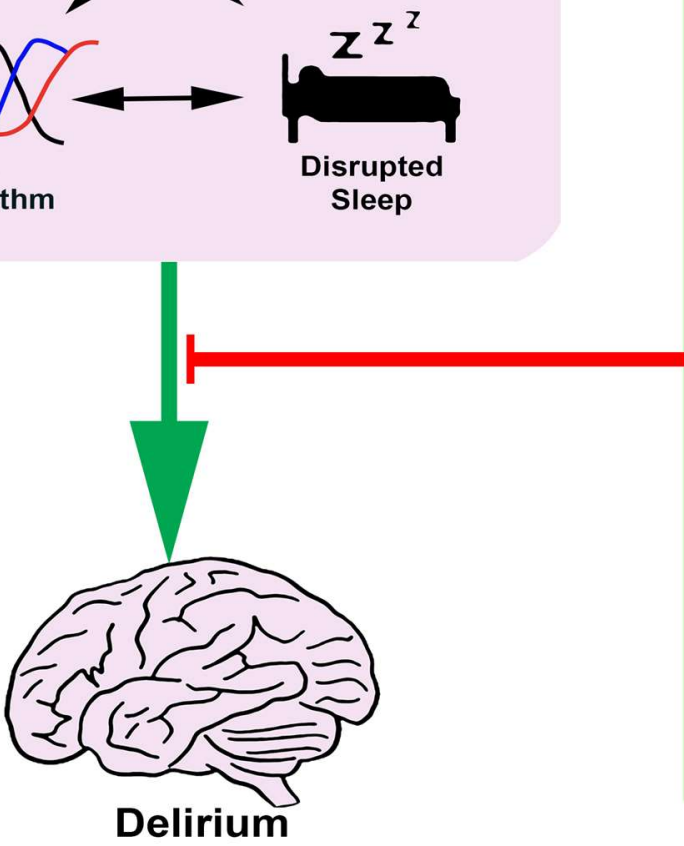

Environmental Interventions

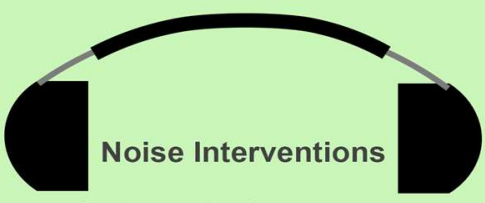

Noise reduction

Architectural acoustic features

Behavioral strategies

Alarm modification

Noise transmission abatement

Earplugs

Headphones

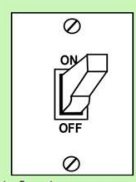

Light Interventions

Improving day-light exposure

Windowed room

Dynamic lighting

Bright light therapy

Decreasing night-light exposure

Dimmed lights

Eye masks

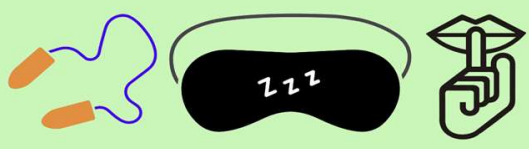

Intervention Bundles

Quiet time

Sleep promotion programs 
medRxiv preprint doi: https://doi.org/10.1101/2020.05.20.20108373; this version posted May 28, 2020. The copyright holder for this preprint

(which was not certified by peer review) is the author/funder, who has granted medRxiv a license to display the preprint in perpetuity.

It is made available under a CC-BY-NC 4.0 International license .

\section{Architectural design}

In this review, two of the studies $[18,47]$ explored a modified ICU design. One study altered the acoustical design of the ICU ${ }^{18}$, whereas the other used a multi-aspect architectural design intervention ${ }^{47}$. Results were mixed, but subtly suggest the benefit of architectural designs that consider acoustic features. Zaal et al. ${ }^{47}$ assessed patient outcomes in a multi-bed ICU room with less natural light and more noise exposure versus a private room with improved daylight and reduced noise by sound absorbers, glass sliding doors, optimized alarms, and remotely controlled monitors. There was no effect on delirium incidence or severity, but they found a reduction of delirious days in the study group by 0.4 (95\% confidence interval (CI) $0.1-0.7, p=0.005)$. Another quasi-randomized study ${ }^{18}$ conducted noise reduction by refurbishing an ICU room. They installed a wall-to-wall drop ceiling, low frequency sound absorbers, and used a visually plain design. The study deemed feasible, requiring improvements in noise measurements and delirium assessments. Given the small sample size $(n=31)$ and feasibility nature of study, no further statistical analysis of outcomes was performed; Delirium developed in 33\% (2/6) versus $25 \%(5 / 25)$ of study versus control patients. There was a slight reduction in noise reverberation and increase in speech clarity in the modified room, though sound levels remained higher than the WHO recommendations ${ }^{17}$.

\section{Noise modification}

In this review, there were two approaches to mitigate patient exposure to excessive sound. One was to reduce source noise by utilizing behavioral strategies and device/alarm optimization. The other was noise abatement by earplugs. No studies investigated impacts of behavioral modification on delirium as an independent intervention, but this strategy was used as part of an environmental modification bundle in 4 studies ${ }^{7,14,57,58}$. Earplugs were mostly a component of an environmental bundle 7, 14, 56, 57, though one study evaluated the effect of earplugs as a single-component intervention ${ }^{48}$. One article implemented a combination of behavioral strategies and earplugs to reduce excessive noise ${ }^{14}$. There were mixed findings across studies with noise modification component(s), but results suggest behavioral strategies and earplugs together might help delirium prevention, particularly as part of a multi-disciplinary program 
medRxiv preprint doi: https://doi.org/10.1101/2020.05.20.20108373; this version posted May 28, 2020. The copyright holder for this preprint (which was not certified by peer review) is the author/funder, who has granted medRxiv a license to display the preprint in perpetuity.

It is made available under a CC-BY-NC 4.0 International license .

targeting environmental risk factors. However, implementation of sustained behavioral changes and tolerability of earplugs remain challenges ${ }^{56}$.

Van de Pol et al. ${ }^{14}$ analyzed the impact of noise reduction on 421 non-delirious ICU patients in an interrupted time series before-after study. They used earplugs and behavioral strategies, including limited bedside conversations, lowered voices, grouped care activities, optimized alarm settings, minimized alarm volume, and closed room doors. Reported noise levels were still higher than the WHO limit post-intervention ${ }^{17}$, however there was a significant decrease in delirium incidence by $3.7 \%$ per time interval $(p=0.02)$, and reduction in sleep medication usage $(p<0.0001)$ in the study group. Perceived night-time noise was improved, but with no effect on sleep quality or use of delirium medication. Van Rompaey et al. show associations between environmental noise, sleep perception, and delirium ${ }^{48}$. They conducted a randomized control trial on 136 non-delirious ICU patients and found use of earplugs (from 2200 to 0600 ) reduced risk of confusion or delirium by $53 \%$ (hazard ratio $0.47,95 \% \mathrm{CI}$ 0.27-0.82) and improved sleep perception.

Our full-text review and data extraction appraised articles studying single-component noise control strategies, such as behavioral programs ${ }^{62-66}$, earplugs or noise cancelling headphones ${ }^{67-71}$, and headphones equipped with an alarm filtering system ${ }^{72}$; however these were not included since they reviewed the impact of interventions on the level of noise or quality of sleep, but delirium was not reported as an outcome (Excluded studies; Supplementary Table 3).

\section{Light modification}

Light interventions were implemented in an attempt to realign circadian rhythms by reducing night-time exposure and/or improving natural or artificial daylight exposure.

\section{Reduction of nocturnal light exposure}

In this review, eye mask use ${ }^{7,56,58}$, and overnight light dimming $7,57,58$ were encouraged as part of an environmental modification bundle to reduce night-time light exposure. No studies evaluated effects of less nocturnal light exposure on delirium as single interventions. 
medRxiv preprint doi: https://doi.org/10.1101/2020.05.20.20108373; this version posted May 28, 2020. The copyright holder for this preprint (which was not certified by peer review) is the author/funder, who has granted medRxiv a license to display the preprint in perpetuity. It is made available under a CC-BY-NC 4.0 International license .

Three observational studies ${ }^{30,32,73}$ and one before-after study ${ }^{47}$ investigated improved natural lighting via windows. They compared patient outcomes in rooms with a window or larger-sized windows versus windowless or smaller-sized windows, respectively. No observational studies suggested association between improved natural lighting and delirium ${ }^{30,32,73}$. Zaal et al. ${ }^{47}$ demonstrated reduction in delirium duration, comparing patients in private rooms with more natural light versus less bright multibed rooms; however, there was no difference in delirium incidence or severity between groups.

\section{Improving artificial daylight exposure}

Eight studies examined effect of improved daylight exposure via artificial lighting, of which three used an artificial circadian lighting system ${ }^{15,49,50}$, and five used bright light therapy (BLT) ${ }^{51-55}$. None of the three studies implementing artificial dynamic or circadian lighting revealed significant effects on delirium. BLT studies had mixed results; three studies significantly improved delirium prevention or management, while other two showed a non-significant tendency to reduce delirium rates.

A retrospective cohort study of 183 non-sedated ICU patients by Estrup et al. ${ }^{15}$ used a circadian lighting system from 0700 to 2300 which varied in intensity and color temperature. During the morning, light intensity was greatest, up to 4000 lux (lx), and the amount of blue light strongest. As the day progressed, light intensity decreased and color temperature shifted towards warmer tones until no blue light was present. There was no improvement in delirium incidence, and no association between receiving circadian lighting and delirium incidence (odds ratio (OR) 1.14; 95\% CI 0.55, 2.37; $\mathrm{p}=0.73$ ). Pustjens et al. ${ }^{49}$ retrospectively studied a cohort of 748 non-sedated patients. They implemented a dynamic lighting system consisting of two ceiling-mounted light-emitting diode (LED) panels which delivered variable intensities of light (peak of 750 lx) with a color temperature between 2700 and 6500 Kelvin (K). There was no effect on delirium incidence. Another RCT by Simons et al. ${ }^{50}$ measured effects of a dynamic lighting application (DLA) in 734 ICU patients. DLA was administered through ceiling-mounted fluorescent lights which delivered a variety of bluish-white light from 0700 to 2230 with a maximum intensity of $17001 \mathrm{x}$ and a maximum temperature of $4300 \mathrm{~K}$ between 0900 and 1600, except between 1130 and 1330 when light intensity was 300 lx. This study was terminated before reporting final results, but 
medRxiv preprint doi: https://doi.org/10.1101/2020.05.20.20108373; this version posted May 28, 2020. The copyright holder for this preprint (which was not certified by peer review) is the author/funder, who has granted medRxiv a license to display the preprint in perpetuity.

It is made available under a CC-BY-NC 4.0 International license .

preliminary analysis demonstrated delirium incidence of $38 \%$ versus $33 \%$ in control versus study patients, with no significant improvement on delirium incidence or duration in the study group.

Four studies investigated use of BLT as a single-component intervention to prevent ${ }^{51,52,55}$ or treat ${ }^{53}$ delirium, while one study used BLT as an element of a multi-component bundle to manage delirium ${ }^{54}$. BLT consisted of exposure to high intensity light (2000 to $10000 \mathrm{~lx}$ ) for one to four hours daily. Three studies used a peak intensity of $50001 \mathrm{x}^{51,52,55}$. Taguchi et al. ${ }^{51}$ conducted a randomization pilot study on 11 post-operative patients, utilizing a daily light intensity of 5000 lx from 0730 to 0930 for days 2 through 5 post-surgery. Delirium assessment scores decreased on day 3 of BLT $(p=0.014)$, but there was no significant effect to overall delirium incidence ( $16 \%$ versus $40 \%$ study versus control group, $\mathrm{p}=0.42$ ). In another RCT, Ono et al. ${ }^{52}$ applied BLT on 22 post-operative patients, for two hours from 0730 to 0930 for four days. Light intensity started at $2500 \mathrm{~lx}$, increasing to $5000 \mathrm{~lx}$, then decreasing to $2500 \mathrm{~lx}$. There was a non-significant tendency towards lower rates of delirium in the study group ( 1 of 10 patients) versus control group (5 of 12 patients), while BLT significantly reduced the amount of activity during sleep of day 4 and 5. Potharajaroen et al. ${ }^{55}$ studied 62 post-operative patients by implementing BLT at $50001 \mathrm{x}$ with a constant intensity from 0900 to 1100 . Eleven of 31 control patients versus 2 of 31 patients in the intervention group developed delirium. There was a significant association between BLT and decreased delirium incidence (OR $0.12,95 \%$ CI $0.03-0.54, p=0.005)$. A study by Yang et al. ${ }^{53}$ on 36 delirious patients used a higher light intensity (10000 lx) over a shorter period (0700 to 0800). This study investigated the use of BLT as an adjunctive treatment of delirium with risperidone. They found a significant decrease in delirium severity in patients receiving BLT in addition to risperidone (DRS $23.9 \pm$ 4.9 versus $20.6 \pm 3.6$ in control versus study group, $p=0.03$ ). Chong et al. ${ }^{54}$ studied 228 delirious elderly patients admitted to a delirium management unit. They incorporated lower intensity BLT as part of their multi-component program, and exposed patients to 2000 to $3000 \mathrm{~lx}$ of light for four hours from 1800 to 2200 daily. They reported significant improvement in total sleep time and functional outcomes during treatment of delirious patients. 
medRxiv preprint doi: https://doi.org/10.1101/2020.05.20.20108373; this version posted May 28, 2020. The copyright holder for this preprint (which was not certified by peer review) is the author/funder, who has granted medRxiv a license to display the preprint in perpetuity.

It is made available under a CC-BY-NC 4.0 International license .

\section{Earplugs and eye mask}

One reviewed study explored effects of earplugs and an eye mask on delirium ${ }^{56}$, while two others used earplugs and an eye mask as part of their interventional bundle ${ }^{7,58}$. All three decreased incidence of delirium, but had different effects on sleep quality. Demoule et al. ${ }^{56}$ conducted a RCT on 43 non-sedated ICU patients to investigate impact of sleeping with earplugs and an eye mask from 2200 to 0800 on patient outcomes. They found no improvement in delirium incidence or duration or architecture of sleep in the study group, regardless of patient compliance using the equipment. Although compliant study subjects experienced improved sleep with longer N3 (deeper sleep) duration and a lower number of prolonged awakenings, there was no significant change in delirium incidence. There were several articles in our initial screening reporting improved perceived noise or sleep quality with use of earplugs and eye mask, however those were excluded since none reported results on delirium ${ }^{74-77}$ (Excluded studies; Supplementary Table 3).

Quiet time, and sleep promotion bundles

Quiet time is a specific amount of time during which modifiable noise and light is actively reduced. Our review included three studies installing quiet time as the single interventional element ${ }^{57}$ or as a part of a sleep promotion bundle ${ }^{7,58}$. Core elements of quiet time were behavioral strategies, minimized bedside activity by clustering care, reduced volume of devices/alarms, and dimmed lights ${ }^{7,57}$, ${ }^{58}$. The study that implemented daytime quiet time failed to show significant effects on delirium ${ }^{57}$, while two sleep promotion studies decreased delirium incidence using nocturnal quiet time combined with components such as earplugs, eye masks, and pharmacological targets ${ }^{7,58}$. Although the multi-component sleep promotion trials decreased delirium incidence, effectiveness of the separate components is unclear.

McAndrew et al. ${ }^{57}$ applied quiet time from 1400 to 1600 among 72 mechanically ventilated ICU patients. In the 24 hours after starting quiet time, there was no increase in delirium rate and $19 \%$ of delirious patients improved to a negative CAM-ICU status. However, there was no significant effect on delirium in their analysis. Quiet time did lead to moderately improved sleep quality and less frequently administered sedatives which helped remove patients from mechanical ventilation. A pre-post research by 
medRxiv preprint doi: https://doi.org/10.1101/2020.05.20.20108373; this version posted May 28, 2020. The copyright holder for this preprint (which was not certified by peer review) is the author/funder, who has granted medRxiv a license to display the preprint in perpetuity.

It is made available under a CC-BY-NC 4.0 International license .

Patel et al. ${ }^{7}$ studied a nocturnal multidisciplinary environmental sleep promotion program in 338 nondelirious, non-sedated ICU patients. Their program included nocturnal quiet time with earplugs, eye mask, patient orientation, early mobilization, and sedation targets. The study group showed significant reduction in delirium incidence (by $33 \% \mathrm{p}<0.001)$, and a decrease in delirium duration $(3.4 \pm 1.4$ versus $1.2 \pm 0.9$ days, $\mathrm{p}=0.021)$. Sleep quality and night-time light and noise levels were also improved in the study group, however reported noise levels were still higher than the WHO limits ${ }^{17}$. They additionally reported a significant association between sleep efficiency and lower risk of developing delirium (OR 0.90, 95\% CI 0.84-0.97). A larger pre-post study $(\mathrm{n}=300)$ by Kamdar et al. ${ }^{58}$ initiated a multi-faceted sleep promotion protocol consisting of three additive stages: 1) nightly quiet time and realignment of circadian rhythm, 2) sleeping with earplugs, eye masks, and soothing music, and 3) pharmacological targets to reduce sedatives. They reported decreased delirium incidence $(\mathrm{OR}=0.46,95 \% \mathrm{CI} 0.23-0.89, \mathrm{p}$ $=0.02$ ) and perceived night-time noise in the study group, but no improvements in sleep quality.

\section{DISCUSSION}

In this scoping review, existing literature was searched for studies on the impact of environmental risk factors and interventions on delirium: 21 studies were retrieved reporting effects of environmental risk factors on delirium and 16 studies reported experiments on possible solutions to modify the environment. Small sample sizes, heterogeneous study methods, and inconsistent results among reviewed studies proved the need for expanding research on impacts of environmental risk factors and efficacy of mitigations related to delirium.

\section{Modifiable ICU environmental risk factors for delirium}

It is well recognized that ICU environments with round-the-clock activities and a high-tech setting have a negative impact on patients' experience and clinical outcomes due to excessive noise, light, and disturbed sleep and circadian rhythm ${ }^{13,47,48}$.

Noise 
medRxiv preprint doi: https://doi.org/10.1101/2020.05.20.20108373; this version posted May 28, 2020. The copyright holder for this preprint (which was not certified by peer review) is the author/funder, who has granted medRxiv a license to display the preprint in perpetuity. It is made available under a CC-BY-NC 4.0 International license .

The WHO set recommendations for hospitals not to exceed an average of $30 \mathrm{dBA}$ or a maximum of $35 \mathrm{dBA}$ in treatment areas (maximum of $40 \mathrm{dBA}$ at night) ${ }^{17}$. A 2016 study by Hu et al. found average sound levels of $62.8 \mathrm{~dB}$, with a mean level of $59.6 \mathrm{~dB}$ between $0000-0700$, when investigating sound in various ICUs ${ }^{78}$. Consistently, five reviewed articles measuring ICU sound pressure with or without noise modification interventions reported levels exceeding the WHO recommendations ${ }^{14,18-20}$.

A 2009 WHO report set night-time noise guidelines and reported on relationships between nighttime noise, sleep, and health. According to the report, excessive night-time noise (above $35 \mathrm{~dB}$ ) disturb sleep, provoke annoyance and agitation, reduce cognition, impair communication and comprehension of surroundings, and contribute to psychiatric disorders. The combination of sleep disruption, decreased cognitive function, and lowered comprehension of surroundings associated with high noise levels may contribute to acute confusion and delirium ${ }^{79,80}$. In our review, two of three observational studies investigating association between high noise levels and ICU delirium found no significant effect of high noise levels on delirium incidence ${ }^{19,20}$. This result is surprising as it has been suspected that noise levels exceeding a normal threshold have detrimental effects on patient recovery, especially with regard to sleep and mental status. It is worth considering the difficulty in assessing the true effect of high noise levels in these two studies. First, there is no available baseline research to compare delirium incidence in high noise level ICUs versus those with statistically lower decibel values. It is possible the threshold for adverse effects is lower or higher than the most recently investigated decibel levels. In addition, Knauert et al. ${ }^{19}$ mentioned a limitation for their study was inadequate statistical power to detect differences in decibel level between patient comparisons. For the study by Johansson et al. ${ }^{20}$, their results need to be taken in context of using a non-validated delirium diagnosis protocol.

\section{Light}

During the daytime, normal light intensity is around $10000 \mathrm{~lx}$ and recommended night-time light levels conducive to sleep are below $301 \mathrm{x}^{59}$. Natural fluctuation of light levels throughout the day contributes to the natural sleep-wake cycle by triggering release and suppression of melatonin. Alteration of the sleep-wake cycle and lack of daylight schedule have been shown to be associated with psychiatric 
medRxiv preprint doi: https://doi.org/10.1101/2020.05.20.20108373; this version posted May 28, 2020. The copyright holder for this preprint (which was not certified by peer review) is the author/funder, who has granted medRxiv a license to display the preprint in perpetuity.

It is made available under a CC-BY-NC 4.0 International license .

diseases including depression, dementia, and delirium ${ }^{59}$. Day-time light levels in the ICU are below normal daylight levels and above the threshold for sleep disruption at night ${ }^{59}$. In a study by Hu et al. light intensity was measured over 24 hours near windows, in the center of rooms, and at eye level of mechanically ventilated patients. Average light intensity at these locations were 425 lx, 191 lx, and 388 lx respectively over 24 hours and 84 lx, 103 lx, and 87 lx between 2401 and $0759{ }^{78}$. Minimal variation in daytime and night-time light levels disrupts the natural sleep-cycle and may contribute to patients becoming unable to distinguish day from night.

Abnormal natural light cycles are cited in recent literature as a potential modifiable risk factor for delirium management ${ }^{59}$. Seven studies analyzing the impact of natural light on delirium incidence suggest this element of the ICU lacks a definitive causative relationship with development of the condition. Most of these studies enrolled critically ill patients whose condition gives them a higher likelihood of having consistently closed eyes compared to the general hospital population. It should be considered for future research that these patients' retinas may not receive the same strength light stimulus as other populations, suggesting the need for ICU-specific lighting strategies. For the two seasonal studies, one found delirium was diagnosed significantly more in the winter than summer ${ }^{29}$, while the other found exhaustive evidence ruling out a link between delirium and pre-hospital photoperiod exposure year-round ${ }^{31}$. These findings suggest there are factors aside from seasonal light exposure affecting delirium. Additionally, of the three studies with a positive correlation between exposure to natural daylight or season of admission, the two natural daylight studies had vague descriptions of their measurements of patient's exposure to natural or artificial light ${ }^{13,46}$. It is hard to assess whether the patient could have received benefits when the proximity of the stimulus to the patient is unclear.

As with excessive noise levels, further research into abnormal natural lighting cycles is necessary to delineate any threshold for adverse effects to patients' well-being.

Sleep

Similar to our findings regarding effects of noise and light levels on delirium, reviewed articles on sleep showed mixed results for both forms of measure (electronic sleep monitoring and subjective 
medRxiv preprint doi: https://doi.org/10.1101/2020.05.20.20108373; this version posted May 28, 2020. The copyright holder for this preprint (which was not certified by peer review) is the author/funder, who has granted medRxiv a license to display the preprint in perpetuity.

It is made available under a CC-BY-NC 4.0 International license .

reports). Recent literature states sleep is disturbed in ICU patients regardless of delirium ${ }^{19,41}$, and this concern is supported by the fact that unmeasurable sleep was found in non-delirious patients in included PSG studies. It is hard to compare results of included wireless monitoring studies, since different methodologies were used for each study, with different devices, leads, and whether or not they followed American Academy of Sleep Medicine standards. Similarly, it is difficult to compare findings from objective sleep monitoring protocols and subjective survey methods, and these need separate consideration. A major concern with analyzing subject sleep quality in delirious patients is patients with an altered mental state and/or confusion may not answer consistently or truthfully, and measures must be taken to assess whether answers are a correct representation of their condition.

\section{Environmental solutions to prevent or manage delirium}

\section{Noise modification}

The negative impact of patient exposure to noise led to several studies focusing on noise pollution in the clinical environment. Mitigated exposure to noise levels might promote patient outcomes and staff satisfaction ${ }^{57,81}$. Noise reduction or abatement strategies include architectural features, behavioral alterations, alarm optimization, earplugs, headphones, and noise cancelling devices. Whilst these strategies have been studied in relation with improved noise levels and sleep promotion (Supplementary Table 3), further research is required to make evidence-based recommendations for the effect of noise reduction on delirium prevention and treatment.

Implementing ICU designs with acoustic features such as sound absorbers, reversible drawers to open both inside and outside the room, or room designs with the ability to locate alarmed devices or transfer alarms away from the patient, might improve exposure to noise and benefit delirium management 47, 82, 83. Zaal et al. demonstrated a lower delirium duration by modifying ICU design with acoustic considerations, however there was no change in delirium incidence rate ${ }^{47}$. These strategies require major renovation or early construction planning, and further research is required to confirm cost-effectiveness and clinical benefits. 
medRxiv preprint doi: https://doi.org/10.1101/2020.05.20.20108373; this version posted May 28, 2020. The copyright holder for this preprint (which was not certified by peer review) is the author/funder, who has granted medRxiv a license to display the preprint in perpetuity. It is made available under a CC-BY-NC 4.0 International license .

Staff and family conversations and care-activities are significant sources of ICU noise pollution 16, 62, 63. Although behavioral modification might be ineffective as a single-component intervention ${ }^{64}$, lowcost adjustments such as limited bedside conversation, lowered voices, clustered care-activities, minimized TV and overhead use and volume, using vibrating pagers, and visual noise-warning devices may be necessary to achieve better results in sound reduction ${ }^{7,14,62,63,65,66}$, sleep improvement ${ }^{63}$, and decreased delirium ${ }^{14}$. To be successful, continuous awareness, education of staff on the impact of excessive noise exposure, and routine monitoring of implemented strategies is crucial ${ }^{7}$. Technologies that help staff and visitors recognize excessive noise might complement implementation of behavioral strategies. Visual noise-warning devices display colored warnings at higher levels of noise and can be an effective, sustained noise reduction strategy ${ }^{65,66}$. Use of noise-warning systems has a greater impact on reduction of ambient noise compared with peak noise levels ${ }^{65,66}$. This is likely a result of change in staff behavior after visual warning while having no effect on medical equipment or alarms.

Alarms are a significant source of ICU noise pollution ${ }^{16,62}$, and a large portion are considered false positives ${ }^{84}$. Studies show modifying ICU alarms by lowering volume, optimizing device settings, and filtering false alarms may reduce disturbing alarm noise ${ }^{85-87}$. Schlesinger and colleagues equipped wearable earbuds with a frequency-selective silencing device, which could successfully filter ICU alarms while allowing patients to hear and communicate effectively without experiencing negative consequences of audible alarms ${ }^{72}$. Optimization of alarms was used as an element of a noise reduction bundle and sleep promotion studies of this scoping review ${ }^{7,14,58}$.

Abating environmental noise by earplugs or headphones appears feasible and effective to reduce noise and improve sleep in the ICU ${ }^{48,56,67-70}$. Here, one study failed to prove benefits of using earplugs and eye masks during sleep on delirium ${ }^{56}$, while another earplug trial decreased risk of confusion, and delayed initiation of cognitive disturbances with no significant effect on incidence of delirium ${ }^{48}$. Given the potential effectiveness and low costs, this method is frequently used in multi-component interventions 7, 58; however, non-compliancy is a major implementation issue in earplugs studies ${ }^{56}$. A recent metaanalysis ${ }^{81}$ reported a $13.1 \%(95 \% \mathrm{CI}, 7.8-25.4)$ rate of non-compliancy due to intolerance, anxiety, or 
medRxiv preprint doi: https://doi.org/10.1101/2020.05.20.20108373; this version posted May 28, 2020. The copyright holder for this preprint (which was not certified by peer review) is the author/funder, who has granted medRxiv a license to display the preprint in perpetuity.

It is made available under a CC-BY-NC 4.0 International license .

accidental removal of earplugs. Headphones with active noise cancellation technology might improve patient outcomes by mitigating exposure to noise. Gallacher et al. modeled an experiment by embedding sound meters in the auditory meatus of polystyrene model heads located near patients' beds in a cardiac $\mathrm{ICU}^{70}$. They demonstrated a significant reduction in overall noise exposure and exposure to high intensity noises using noise cancelling headphones.

Despite inconsistent results of the reviewed studies on efficacy of noise modifications on delirium, this review suggests considering physical design features and multi-component noise reduction programs may benefit delirium prevention or management. This is consistent with current recommendations suggesting multi-component interventions to achieve adequate noise reduction ${ }^{81}$; Van de Pol et al. ${ }^{14}$ reduced delirium incidence by implementing a noise reduction program consisting of behavioral strategies, device optimization, and earplugs. However, there is a need for high-quality randomized control trials with larger sample sizes to evaluate efficacy, sustainability, and long-term effects of noise modification interventions with a focus on delirium.

\section{Light modification}

Optimized circadian rhythm needs bright days and dark nights. Various light modification strategies have been proposed to follow circadian rhythms. These are categorized as such: decreasing night-time light exposure, and increasing daylight.

Round-the-clock ICU activities make nigh-time light reduction challenging to maintain a level of light sufficient for providing care, but not disturbing sleep. Dimming lights as part of quiet time strategies is effective to mitigate intensity of light during quiet time hours, however, this may cause variation in perceived light and consequently cause sleep disturbance ${ }^{87}$. Possible solutions are clustering careactivities to reduce bedside interruptions ${ }^{7}$ and use of portable lighting pods with less blue wavelength during the night ${ }^{88}$. Whilst the trial of sleep mask and earplugs by Demoule at al. ${ }^{56}$ failed to show benefit to delirium, eye masks are effective in promoting sleep by light abatement ${ }^{7,74,76,77}$. However, poor compliance using eye masks due to accidental removal, or anxiety/claustrophobia, and the risk of sensory deprivation in mechanically ventilated patients, remains challenging ${ }^{56}$. 
medRxiv preprint doi: https://doi.org/10.1101/2020.05.20.20108373; this version posted May 28, 2020. The copyright holder for this preprint (which was not certified by peer review) is the author/funder, who has granted medRxiv a license to display the preprint in perpetuity.

It is made available under a CC-BY-NC 4.0 International license .

Environmental modification to increase daylight exposure is possible through architectural considerations of promoting natural lighting or utilizing artificial illumination. Research into whether windows allow enough light to promote sleep-wake cycles and prevent delirium, and whether seasonal light levels contribute to delirium, has been conducted with inconclusive findings ${ }^{30,32,73}$. From our results, the greatest interventional effect on delirium was from bright light therapy.

Our review included five studies on BLT, three reporting a significant effect on delirium incidence or severity ${ }^{51,53,55}$ with sleep promoted in four studies ${ }^{52-55}$. BLT has the greatest effect between 2500 and $10000 \mathrm{~lx}$ for 30 to 60 minutes, with a shorter duration for greater intensities of light, when administered either at twilight or dawn to obtain a circadian effect ${ }^{60}$. The BLT in this review applied $2000-10000$ lx of illuminance for between one and four hours. The use of 2000 lx was effective in improving sleep quantity and functional status during management of delirium as part of a bundle. The use of 5000 lx was associated with decreased delirium incidence in two of three studies and the use of $10000 \mathrm{~lx}$, as an adjunctive treatment with risperidone, was associated with a decrease in delirium severity 53. While BLT may help regulate sleep-wake cycles and prevent/treat delirium, research into melatonin secretion and circadian rhythms suggests periods of darkness play as large a role as daytime light levels in promoting sleep and preventing delirium ${ }^{59,89}$. The importance of light and darkness prompts a need for research into effects of dynamic lighting systems. This review included three studies focused on dynamic lighting among sedated and non-sedated patients, using lighting systems which produced cooler blue light in the mornings and shifted towards warmer tones as the day progressed. The lighting systems produced different levels of intensity throughout the day, reaching a peak of between 750 and $4000 \mathrm{~lx}$ and a minimum level of 0 lx. None of these studies showed significant effects on delirium ${ }^{15,49,50}$; however, they used peak light levels below normal daytime levels.

Maintaining a circadian rhythm, by nocturnal darkness and BLT, as a low-cost, low-risk, easy-toapply intervention can help improve patient outcomes. Research is required to investigate the use of dynamic lighting with higher peak light intensities or the combination of dynamic lighting and BLT. Additionally, there is a need for defining effective characteristics of light modification strategies for 
medRxiv preprint doi: https://doi.org/10.1101/2020.05.20.20108373; this version posted May 28, 2020. The copyright holder for this preprint (which was not certified by peer review) is the author/funder, who has granted medRxiv a license to display the preprint in perpetuity.

It is made available under a CC-BY-NC 4.0 International license .

sedated and non-sedated patients. Sedated patients may have disrupted circadian rhythm of melatonin ${ }^{90}$, and application of light therapies might have limited retina stimuli when eyes are closed. Studies comparing efficacy of light modifications on prevention or treatment of delirium among these two groups of patients, with application of different intensity levels of light in closed-eyes patients, might be of benefit.

\section{Intervention bundles (light and noise modification)}

There is a growing interest in using quiet time interventions to promote sleep. Quiet time is defined as a designated period of time in which there is a limitation in bedside interruptions and a reduction in noise and light levels. Quiet time protocols have successfully reduced sound pressure, improved sleep quality, and reduced the use of sedatives ${ }^{87,91-94}$, but effects of quiet time on delirium development needs further research. McAndrew et al. implemented a daily quiet time protocol in ICU patients and reported inconclusive results on delirium scores and moderate improvement in sleep perception ${ }^{57}$. Two neurocritical ICU studies have implemented a two hour quiet time during day and night ${ }^{93,94}$. A significant improvement in subjective sleep and increased staff satisfaction was achieved ${ }^{93}$,

${ }^{94}$. They reported decreased light by $75-85 \%$ and noise by $15 \%$, with results being more significant during day-shift quiet time; this might be due to overall lower levels of nocturnal light and noise ${ }^{93}$.

Sleep promotion protocols utilize noise and light control strategies with other components, such as patient orientation, early mobilization, medication optimization, and sedation targets to improve sleep in quality and quantity. Here we included two sleep promotion studies reporting results on delirium, however future research is needed to evaluate which component of sleep promotions are effective in reducing delirium. Patel et al. ${ }^{7}$ significantly improved sleep quality and reduced delirium incidence by implementing a non-pharmacological multidisciplinary sleep program. They raised protocol compliance to $>90 \%$ by ongoing education, signage and posters, monitoring, and spot-checking program quality by experienced nurse champions. Interestingly, a large sleep promotion study by Kamdar et al., decreased delirium incidence while there was no effect on sleep ${ }^{58}$. It is not clear if improvements in delirium are 
medRxiv preprint doi: https://doi.org/10.1101/2020.05.20.20108373; this version posted May 28, 2020. The copyright holder for this preprint (which was not certified by peer review) is the author/funder, who has granted medRxiv a license to display the preprint in perpetuity.

It is made available under a CC-BY-NC 4.0 International license .

attributable to sleep, emphasizing the need for future studies focused on single interventions or single components of multifaceted interventions with regard to delirium results.

The main strength of this review is synthesizing results of both observational association studies and interventional studies. This approach details a broader picture of the current state of this research field and bridges the gap between establishing correlational relationships and continuation of experimental trials. A major limitation of this review is the narrow search method. By searching one database (Pubmed) and the included articles' reference lists, there is likely additional literature available to expand our findings, however the authors did a hand search within related journals, Embase, and Google Scholar databases to include existing interventional research articles. Another limitation was generated data from reviewed studies did not have full details, and quality of evidence was not evaluated among studies; however, this review was intended to be a literature mapping with limited description of relevant publications.

\section{CONCLUSION}

This review of studies investigating the association between delirium and either high noise levels, abnormal amounts of natural daylight, and/or sleep disruptions did not reveal a clear relationship between delirium and these variables. It is recommended to perform additional research into more comprehensive, but related, risk factors to find a stronger predictor. Additional research could include analyses of specific noise sources or a comparison between overcast, rainy, and sunny times. This study demonstrated overall evidence supporting effectiveness of environmental interventions on delirium is of low confidence. Current literature lacks randomized control trials with larger sample sizes to evaluate efficacy of intervention on delirium and its long-term outcomes. Another knowledge gap is lack of adequate conclusive research on single-component interventions. The interventional bundle studies lead to uncertainty about which component impacts the result. Given the low-cost and non-invasive nature of environmental modifications and their potential beneficial role in reduction of modifiable risk factors, it is 
medRxiv preprint doi: https://doi.org/10.1101/2020.05.20.20108373; this version posted May 28, 2020. The copyright holder for this preprint (which was not certified by peer review) is the author/funder, who has granted medRxiv a license to display the preprint in perpetuity.

It is made available under a CC-BY-NC 4.0 International license .

recommended to implement these interventions in current practice, especially as multi-component bundles. 
medRxiv preprint doi: https://doi.org/10.1101/2020.05.20.20108373; this version posted May 28, 2020. The copyright holder for this preprint

(which was not certified by peer review) is the author/funder, who has granted medRxiv a license to display the preprint in perpetuity.

It is made available under a CC-BY-NC 4.0 International license .

\section{REFERENCES:}

1. Lin W-L, Chen Y-F, Wang J. Factors associated with the development of delirium in elderly patients in intensive care units. Journal of Nursing Research. 2015;23(4):322-329.

2. Kalabalik J, Brunetti L, El-Srougy R. Intensive care unit delirium: a review of the literature. Journal of pharmacy practice. 2014;27(2):195-207.

3. Page VJ, Ely EW, Gates S, Zhao XB, Alce T, Shintani A, Jackson J, Perkins GD, McAuley DF. Effect of intravenous haloperidol on the duration of delirium and coma in critically ill patients (HopeICU): a randomised, double-blind, placebo-controlled trial. The Lancet Respiratory Medicine. 2013/09/01/2013;1(7):515-523.

4. Salluh JI, Wang H, Schneider EB, Nagaraja N, Yenokyan G, Damluji A, Serafim RB, Stevens RD. Outcome of delirium in critically ill patients: systematic review and meta-analysis. BMJ. Jun 3 2015;350:h2538.

5. Witlox J, Eurelings LS, de Jonghe JF, Kalisvaart KJ, Eikelenboom P, van Gool WA. Delirium in elderly patients and the risk of postdischarge mortality, institutionalization, and dementia: a meta-analysis. Jama. Jul 28 2010;304(4):443-451.

6. Mehta S, Cook D, Devlin JW, Skrobik Y, Meade M, Fergusson D, Herridge M, Steinberg M, Granton J, Ferguson N, Tanios M, Dodek P, Fowler R, Burns K, Jacka M, Olafson K, Mallick R, Reynolds S, Keenan S, Burry L. Prevalence, risk factors, and outcomes of delirium in mechanically ventilated adults. Crit Care Med. Mar 2015;43(3):557-566.

7. Patel J, Baldwin J, Bunting P, Laha S. The effect of a multicomponent multidisciplinary bundle of interventions on sleep and delirium in medical and surgical intensive care patients. Anaesthesia. Jun 2014;69(6):540-549.

8. Micek ST, Anand NJ, Laible BR, Shannon WD, Kollef MH. Delirium as detected by the CAM-ICU predicts restraint use among mechanically ventilated medical patients*. Critical Care Medicine. 2005;33(6):1260-1265.

9. Ahmed S, Leurent B, Sampson EL. Risk factors for incident delirium among older people in acute hospital medical units: a systematic review and meta-analysis. Age and Ageing. 2014;43(3):326333.

10. Fong TG, Tulebaev SR, Inouye SK. Delirium in elderly adults: diagnosis, prevention and treatment. Nature Reviews Neurology. 2009/04/01 2009;5(4):210-220.

11. Ruppert MM, Lipori J, Patel S, Ingersent E, Ozrazgat-Baslanti T, Loftus T, Rashidi P, Bihorac A. ICU Delirium Prediction Models: A Systematic Review. arXiv e-prints; 2019:arXiv:1911.02548.

12. Davoudi A, Ebadi A, Rashidi P, Ozrazgat-Baslanti T, Bihorac A, Bursian AC. Delirium Prediction using Machine Learning Models on Preoperative Electronic Health Records Data. Proceedings. IEEE International Symposium on Bioinformatics and Bioengineering. 2017;2017:568-573.

13. Van Rompaey B, Elseviers MM, Schuurmans MJ, Shortridge-Baggett LM, Truijen S, Bossaert L. Risk factors for delirium in intensive care patients: a prospective cohort study. Critical Care. 2009/05/20 2009;13(3):R77.

14. van de Pol I, van Iterson M, Maaskant J. Effect of nocturnal sound reduction on the incidence of delirium in intensive care unit patients: An interrupted time series analysis. Intensive Crit Care Nurs. Aug 2017;41:18-25.

15. Estrup S, Kjer CKW, Poulsen LM, Gogenur I, Mathiesen O. Delirium and effect of circadian light in the intensive care unit: a retrospective cohort study. Acta Anaesthesiol Scand. Mar 2018;62(3):367-375.

16. Darbyshire JL, Young JD. An investigation of sound levels on intensive care units with reference to the WHO guidelines. Crit Care. Sep 3 2013;17(5):R187. 
medRxiv preprint doi: https://doi.org/10.1101/2020.05.20.20108373; this version posted May 28, 2020. The copyright holder for this preprint

(which was not certified by peer review) is the author/funder, who has granted medRxiv a license to display the preprint in perpetuity.

It is made available under a CC-BY-NC 4.0 International license .

17. Berglund B, Lindvall T, Schwela DH, World Health Organization O, Environmental Health T. Guidelines for community noise. Geneva: World Health Organization; 1999.

18. Johansson L, Lindahl B, Knutsson S, Ogren M, Persson Waye K, Ringdal M. Evaluation of a sound environment intervention in an ICU: A feasibility study. Aust Crit Care. Mar 2018;31(2):59-70.

19. Knauert M, Jeon S, Murphy TE, Yaggi HK, Pisani MA, Redeker NS. Comparing average levels and peak occurrence of overnight sound in the medical intensive care unit on A-weighted and Cweighted decibel scales. J Crit Care. Dec 2016;36:1-7.

20. Johansson L, Bergbom I, Waye KP, Ryherd E, Lindahl B. The sound environment in an ICU patient room--a content analysis of sound levels and patient experiences. Intensive Crit Care Nurs. Oct 2012;28(5):269-279.

21. Thom RP, Bui MP, Rosner B, Teslyar P, Levy-Carrick NC, Klompas M. A Comparison of Early, Late, and No Treatment of Intensive Care Unit Delirium With Antipsychotics: A Retrospective Cohort Study. Prim Care Companion CNS Disord. Nov 15 2018;20(6).

22. Knauert MP, Pisani MA. Dexmedetomidine for hyperactive delirium: worth further study. $J$ Thorac Dis. Sep 2016;8(9):E999-E1002.

23. Girard TD, Exline MC, Carson SS, Hough CL, Rock P, Gong MN, Douglas IS, Malhotra A, Owens RL, Feinstein DJ, Khan B, Pisani MA, Hyzy RC, Schmidt GA, Schweickert WD, Hite RD, Bowton DL, Masica AL, Thompson JL, Chandrasekhar R, Pun BT, Strength C, Boehm LM, Jackson JC, Pandharipande PP, Brummel NE, Hughes CG, Patel MB, Stollings JL, Bernard GR, Dittus RS, Ely $\mathrm{EW}$, Investigators M-U. Haloperidol and Ziprasidone for Treatment of Delirium in Critical Illness. N Engl J Med. Dec 27 2018;379(26):2506-2516.

24. Chen S, Shi L, Liang F, Xu L, Desislava D, Wu Q, Zhang J. Exogenous Melatonin for Delirium Prevention: a Meta-analysis of Randomized Controlled Trials. Mol Neurobiol. Aug 2016;53(6):4046-4053.

25. Arora RC, Cunningham C. Losing Sleep Over Delirium. Crit Care Med. Jun 2018;46(6):1036-1038.

26. Arksey H, O'Malley L. Scoping studies: towards a methodological framework. International Journal of Social Research Methodology. 2005/02/01 2005;8(1):19-32.

27. Levac D, Colquhoun H, O'Brien KK. Scoping studies: advancing the methodology. Implement Sci. Sep 20 2010;5:69.

28. Tricco AC, Lillie E, Zarin W, O'Brien KK, Colquhoun H, Levac D, Moher D, Peters MDJ, Horsley T, Weeks L, Hempel S, AkI EA, Chang C, McGowan J, Stewart L, Hartling L, Aldcroft A, Wilson MG, Garritty C, Lewin S, Godfrey CM, Macdonald MT, Langlois EV, Soares-Weiser K, Moriarty J, Clifford T, Tuncalp O, Straus SE. PRISMA Extension for Scoping Reviews (PRISMA-ScR): Checklist and Explanation. Ann Intern Med. Oct 2 2018;169(7):467-473.

29. Balan S, Leibovitz A, Freedman L, Blagman B, Ruth M, Ady S, Habot B. Seasonal variation in the incidence of delirium among the patients of a geriatric hospital. Arch Gerontol Geriatr. Nov-Dec 2001;33(3):287-293.

30. Kohn R, Harhay MO, Cooney E, Small DS, Halpern SD. Do windows or natural views affect outcomes or costs among patients in ICUs? Crit Care Med. Jul 2013;41(7):1645-1655.

31. Simons KS, Workum JD, Slooter AJ, van den Boogaard M, van der Hoeven JG, Pickkers P. Effect of preadmission sunlight exposure on intensive care unit-acquired delirium: a multicenter study. $J$ Crit Care. Apr 2014;29(2):283-286.

32. Smonig R, Magalhaes E, Bouadma L, Andremont O, de Montmollin E, Essardy F, Mourvillier B, Lebut J, Dupuis C, Neuville M, Lermuzeaux M, Timsit JF, Sonneville R. Impact of natural light exposure on delirium burden in adult patients receiving invasive mechanical ventilation in the ICU: a prospective study. Ann Intensive Care. Oct 17 2019;9(1):120.

33. Boesen HC, Andersen JH, Bendtsen AO, Jennum PJ. Sleep and delirium in unsedated patients in the intensive care unit. Acta Anaesthesiol Scand. Jan 2016;60(1):59-68. 
medRxiv preprint doi: https://doi.org/10.1101/2020.05.20.20108373; this version posted May 28, 2020. The copyright holder for this preprint

(which was not certified by peer review) is the author/funder, who has granted medRxiv a license to display the preprint in perpetuity.

It is made available under a CC-BY-NC 4.0 International license .

34. Bowman AM. Sleep satisfaction, perceived pain and acute confusion in elderly clients undergoing orthopaedic procedures. J Adv Nurs. Sep 1997;26(3):550-564.

35. Drouot X, Roche-Campo F, Thille A, Cabello B, Galia F, Margarit L, d'Ortho M-P, Brochard L. A new classification for sleep analysis in critically ill patients. Sleep medicine. 12/06 2011;13:7-14.

36. Kamdar BB, Niessen T, Colantuoni E, King LM, Neufeld KJ, Bienvenu OJ, Rowden AM, Collop NA, Needham DM. Delirium transitions in the medical ICU: exploring the role of sleep quality and other factors. Crit Care Med. Jan 2015;43(1):135-141.

37. Kaneko T, Takahashi S, Naka T, Hirooka Y, Inoue Y, Kaibara N. Postoperative delirium following gastrointestinal surgery in elderly patients. Surg Today. 1997;27(2):107-111.

38. Knauert MP, Yaggi HK, Redeker NS, Murphy TE, Araujo KL, Pisani MA. Feasibility study of unattended polysomnography in medical intensive care unit patients. Heart Lung. Sep-Oct 2014;43(5):445-452.

39. Kumar AK, Jayant A, Arya VK, Magoon R, Sharma R. Delirium after cardiac surgery: A pilot study from a single tertiary referral center. Ann Card Anaesth. Jan-Mar 2017;20(1):76-82.

40. Shigeta H, Yasui A, Nimura Y, Machida N, Kageyama M, Miura M, Menjo M, Ikeda K. Postoperative delirium and melatonin levels in elderly patients. Am J Surg. Nov 2001;182(5):449454.

41. Trompeo AC, Vidi Y, Locane MD, Braghiroli A, Mascia L, Bosma K, Ranieri VM. Sleep disturbances in the critically ill patients: role of delirium and sedative agents. Minerva Anestesiol. Jun 2011;77(6):604-612.

42. Whitcomb JJ, Morgan M, Irvin T, Spencer K, Boynton L, Turman S, Rhodes C. A pilot study on delirium in the intensive care unit: a creative inquiry project with undergraduate nursing students. Dimens Crit Care Nurs. Sep-Oct 2013;32(5):266-270.

43. Yildizeli B, Ozyurtkan MO, Batirel HF, Kuscu K, Bekiroglu N, Yuksel M. Factors associated with postoperative delirium after thoracic surgery. Ann Thorac Surg. Mar 2005;79(3):1004-1009.

44. Zhang WY, Wu WL, Gu JJ, Sun Y, Ye XF, Qiu WJ, Su CQ, Zhang SQ, Ye WQ. Risk factors for postoperative delirium in patients after coronary artery bypass grafting: A prospective cohort study. J Crit Care. Jun 2015;30(3):606-612.

45. Davoudi A, Malhotra KR, Shickel B, Siegel S, Williams S, Ruppert M, Bihorac E, Ozrazgat-Baslanti T, Tighe PJ, Bihorac A, Rashidi P. Intelligent ICU for Autonomous Patient Monitoring Using Pervasive Sensing and Deep Learning. Sci Rep. May 29 2019;9(1):8020.

46. Simeone S, Pucciarelli G, Perrone M, Teresa R, Gargiulo G, Guillari A, Castellano G, Tommaso LD, Niola M, lannelli G. Delirium in ICU patients following cardiac surgery: An observational study. J Clin Nurs. May 2018;27(9-10):1994-2002.

47. Zaal IJ, Spruyt CF, Peelen LM, van Eijk MMJ, Wientjes R, Schneider MME, Kesecioglu J, Slooter AJC. Intensive care unit environment may affect the course of delirium. Intensive Care Medicine. 2013/03/01 2013;39(3):481-488.

48. Van Rompaey B, Elseviers MM, Van Drom W, Fromont V, Jorens PG. The effect of earplugs during the night on the onset of delirium and sleep perception: a randomized controlled trial in intensive care patients. Crit Care. May 4 2012;16(3):R73.

49. Pustjens T, Schoutens AM, Janssen L, Heesen WF. Effect of dynamic light at the coronary care unit on the length of hospital stay and development of delirium: a retrospective cohort study. $J$ Geriatr Cardiol. Sep 28 2018;15(9):567-573.

50. Simons KS, Laheij RJ, van den Boogaard M, Moviat MA, Paling AJ, Polderman FN, Rozendaal FW, Salet GA, van der Hoeven JG, Pickkers P, de Jager CP. Dynamic light application therapy to reduce the incidence and duration of delirium in intensive-care patients: a randomised controlled trial. Lancet Respir Med. Mar 2016;4(3):194-202. 
medRxiv preprint doi: https://doi.org/10.1101/2020.05.20.20108373; this version posted May 28, 2020. The copyright holder for this preprint

(which was not certified by peer review) is the author/funder, who has granted medRxiv a license to display the preprint in perpetuity.

It is made available under a CC-BY-NC 4.0 International license .

51. Taguchi T, Yano M, Kido Y. Influence of bright light therapy on postoperative patients: a pilot study. Intensive Crit Care Nurs. Oct 2007;23(5):289-297.

52. Ono H, Taguchi T, Kido Y, Fujino Y, Doki Y. The usefulness of bright light therapy for patients after oesophagectomy. Intensive Crit Care Nurs. Jun 2011;27(3):158-166.

53. Yang J, Choi W, Ko YH, Joe SH, Han C, Kim YK. Bright light therapy as an adjunctive treatment with risperidone in patients with delirium: a randomized, open, parallel group study. Gen Hosp Psychiatry. Sep-Oct 2012;34(5):546-551.

54. Chong MS, Tan KT, Tay L, Wong YM, Ancoli-Israel S. Bright light therapy as part of a multicomponent management program improves sleep and functional outcomes in delirious older hospitalized adults. Clin Interv Aging. 2013;8:565-572.

55. Potharajaroen S, Tangwongchai S, Tayjasanant T, Thawitsri T, Anderson G, Maes M. Bright light and oxygen therapies decrease delirium risk in critically ill surgical patients by targeting sleep and acid-base disturbances. Psychiatry Res. Mar 2018;261:21-27.

56. Demoule A, Carreira S, Lavault S, Pallanca O, Morawiec E, Mayaux J, Arnulf I, Similowski T. Impact of earplugs and eye mask on sleep in critically ill patients: a prospective randomized study. Crit Care. Nov 21 2017;21(1):284.

57. McAndrew NS, Leske J, Guttormson J, Kelber ST, Moore K, Dabrowski S. Quiet time for mechanically ventilated patients in the medical intensive care unit. Intensive Crit Care Nurs. Aug 2016;35:22-27.

58. Kamdar BB, King LM, Collop NA, Sakamuri S, Colantuoni E, Neufeld KJ, Bienvenu OJ, Rowden AM, Touradji $P$, Brower RG, Needham DM. The effect of a quality improvement intervention on perceived sleep quality and cognition in a medical ICU. Crit Care Med. Mar 2013;41(3):800-809.

59. Luther R, McLeod A. The effect of chronotherapy on delirium in critical care - a systematic review. Nurs Crit Care. Nov 2018;23(6):283-290.

60. Madrid-Navarro CJ, Sanchez-Galvez R, Martinez-Nicolas A, Marina R, Garcia JA, Madrid JA, Rol MA. Disruption of Circadian Rhythms and Delirium, Sleep Impairment and Sepsis in Critically ill Patients. Potential Therapeutic Implications for Increased Light-Dark Contrast and Melatonin Therapy in an ICU Environment. Curr Pharm Des. 2015;21(24):3453-3468.

61. Konkani A, Oakley B, Penprase B. Reducing hospital ICU noise: a behavior-based approach. J Healthc Eng. 2014;5(2):229-246.

62. Kahn DM, Cook TE, Carlisle CC, Nelson DL, Kramer NR, Millman RP. Identification and modification of environmental noise in an ICU setting. Chest. Aug 1998;114(2):535-540.

63. Monsen MG, Edell-Gustafsson UM. Noise and sleep disturbance factors before and after implementation of a behavioural modification programme. Intensive Crit Care Nurs. Aug 2005;21(4):208-219.

64. Crawford KJ, Barnes LA, Peters TM, Falk J, Gehlbach BK. Identifying determinants of noise in a medical intensive care unit. Journal of occupational and environmental hygiene. 2018;15(12):810-817.

65. Guisasola-Rabes M, Sola-Enriquez B, Velez-Pereira AM, de Nadal M. Effectiveness of a visual noise warning system on noise levels in a surgical ICU: A quality improvement programme. Eur J Anaesthesiol. Nov 2019;36(11):857-862.

66. Plummer NR, Herbert A, Blundell JE, Howarth R, Baldwin J, Laha S. SoundEar noise warning devices cause a sustained reduction in ambient noise in adult critical care. Journal of the Intensive Care Society. 2019/05/01 2018;20(2):106-110.

67. Wallace CJ, Robins J, Alvord LS, Walker JM. The effect of earplugs on sleep measures during exposure to simulated intensive care unit noise. Am J Crit Care. Jul 1999;8(4):210-219.

68. Scotto CJ, McClusky C, Spillan S, Kimmel J. Earplugs improve patients' subjective experience of sleep in critical care. Nurs Crit Care. Jul-Aug 2009;14(4):180-184. 
medRxiv preprint doi: https://doi.org/10.1101/2020.05.20.20108373; this version posted May 28, 2020. The copyright holder for this preprint

(which was not certified by peer review) is the author/funder, who has granted medRxiv a license to display the preprint in perpetuity.

It is made available under a CC-BY-NC 4.0 International license .

69. Litton E, Elliott R, Ferrier J, Webb SAR. Quality sleep using earplugs in the intensive care unit: the QUIET pilot randomised controlled trial. Crit Care Resusc. Jun 2017;19(2):128-133.

70. Gallacher S, Enki D, Stevens S, Bennett MJ. An experimental model to measure the ability of headphones with active noise control to reduce patient's exposure to noise in an intensive care unit. Intensive Care Medicine Experimental. 2017/10/17 2017;5(1):47.

71. Owen JD, Dunn MJG. Active noise cancelling headphones with white noise to aid sleep in nonventilated, non-delirious critical care patients: a randomised crossover trial. British Journal of Anaesthesia. 2019;123(4):e503.

72. Schlesinger J, Reynolds E, Sweyer B, Pradham A. Frequency-Selective Silencing Device for Digital Filtering of Audible Medical Alarm Sounds to Enhance ICU Patient Recovery; 2017.

73. Arenson BG, MacDonald LA, Grocott HP, Hiebert BM, Arora RC. Effect of intensive care unit environment on in-hospital delirium after cardiac surgery. J Thorac Cardiovasc Surg. Jul 2013;146(1):172-178.

74. Le Guen M, Nicolas-Robin A, Lebard C, Arnulf I, Langeron O. Earplugs and eye masks vs routine care prevent sleep impairment in post-anaesthesia care unit: a randomized study. $\mathrm{Br} J$ Anaesth. Jan 2014;112(1):89-95.

75. Richardson A, Allsop M, Coghill E, Turnock C. Earplugs and eye masks: do they improve critical care patients' sleep? Nurs Crit Care. Nov-Dec 2007;12(6):278-286.

76. Hu RF, Jiang XY, Zeng YM, Chen XY, Zhang YH. Effects of earplugs and eye masks on nocturnal sleep, melatonin and cortisol in a simulated intensive care unit environment. Crit Care. 2010;14(2):R66.

77. Jones C, Dawson D. Eye masks and earplugs improve patient's perception of sleep. Nurs Crit Care. Sep-Oct 2012;17(5):247-254.

78. Hu RF, Hegadoren KM, Wang XY, Jiang XY. An investigation of light and sound levels on intensive care units in China. Aust Crit Care. May 2016;29(2):62-67.

79. Inouye SK, Bogardus ST, Jr., Charpentier PA, Leo-Summers L, Acampora D, Holford TR, Cooney LM, Jr. A multicomponent intervention to prevent delirium in hospitalized older patients. $N$ Engl J Med. Mar 4 1999;340(9):669-676.

80. Inouye SK, Viscoli CM, Horwitz RI, Hurst LD, Tinetti ME. A predictive model for delirium in hospitalized elderly medical patients based on admission characteristics. Ann Intern Med. Sep 15 1993;119(6):474-481.

81. Delaney L, Litton E, Van Haren F. The effectiveness of noise interventions in the ICU. Curr Opin Anaesthesiol. Jan 282019.

82. Ulrich RS, Zimring C, Zhu X, DuBose J, Seo HB, Choi YS, Quan X, Joseph A. A review of the research literature on evidence-based healthcare design. Herd. Spring 2008;1(3):61-125.

83. Luetz A, Weiss B, Penzel T, Fietze I, Glos M, Wernecke KD, Bluemke B, Dehn AM, Willemeit T, Finke A, Spies $C$. Feasibility of noise reduction by a modification in ICU environment. Physiol Meas. Jul 2016;37(7):1041-1055.

84. Lutter NO, Urankar S, Kroeber S. False alarm rates of three third-generation pulse oximeters in PACU, ICU and IABP patients. Anesth Analg. Jan 2002;94(1 Suppl):S69-75.

85. Konkani A, Oakley B, Bauld TJ. Reducing hospital noise: a review of medical device alarm management. Biomed Instrum Technol. Nov-Dec 2012;46(6):478-487.

86. Li SY, Wang TJ, Vivienne Wu SF, Liang SY, Tung HH. Efficacy of controlling night-time noise and activities to improve patients' sleep quality in a surgical intensive care unit. J Clin Nurs. Feb 2011;20(3-4):396-407.

87. Walder B, Francioli D, Meyer JJ, Lancon M, Romand JA. Effects of guidelines implementation in a surgical intensive care unit to control nighttime light and noise levels. Crit Care Med. Jul 2000;28(7):2242-2247. 
medRxiv preprint doi: https://doi.org/10.1101/2020.05.20.20108373; this version posted May 28, 2020. The copyright holder for this preprint

(which was not certified by peer review) is the author/funder, who has granted medRxiv a license to display the preprint in perpetuity.

It is made available under a CC-BY-NC 4.0 International license .

88. Albala L, Bober T, Hale G, Warfield B, Collins ML, Merritt Z, Steimetz E, Nadler S, Lev Y, Hanifin J. Effect on nurse and patient experience: overnight use of blue-depleted illumination. BMJ open quality. 2019;8(3):e000692-e000692.

89. Barroso A, Simons K, de Jager P. Metrics of circadian lighting for clinical investigations. Lighting Research \& Technology. 2014/12/01 2013;46(6):637-649.

90. Olofsson $\mathrm{K}$, Alling $\mathrm{C}$, Lundberg D, Malmros C. Abolished circadian rhythm of melatonin secretion in sedated and artificially ventilated intensive care patients. Acta Anaesthesiol Scand. Jul 2004;48(6):679-684.

91. Bartick MC, Thai X, Schmidt T, Altaye A, Solet JM. Decrease in as-needed sedative use by limiting nighttime sleep disruptions from hospital staff. J Hosp Med. Mar 2010;5(3):E20-24.

92. Boyko $Y$, Jennum $P$, Nikolic $M$, Holst R, Oerding H, Toft P. Sleep in intensive care unit: The role of environment. J Crit Care. Feb 2017;37:99-105.

93. Dennis CM, Lee R, Woodard EK, Szalaj JJ, Walker CA. Benefits of quiet time for neuro-intensive care patients. J Neurosci Nurs. Aug 2010;42(4):217-224.

94. Olson DM, Borel CO, Laskowitz DT, Moore DT, McConnell ES. Quiet time: a nursing intervention to promote sleep in neurocritical care units. Am J Crit Care. Mar 2001;10(2):74-78. 
Table 1: Summary of Characteristics and Findings of Reviewed Observational Association Studies

\begin{tabular}{|c|c|c|c|c|c|c|}
\hline $\begin{array}{c}\text { Study } \\
\text { (Author, Year, } \\
\text { Country) }\end{array}$ & Study Design & $\begin{array}{l}\text { Setting \& Population } \\
\text { Characteristics }\end{array}$ & $\begin{array}{c}\text { Examined Risk } \\
\text { Factors }\end{array}$ & Method Details & Findings & Statistics \\
\hline \multicolumn{7}{|l|}{ Noise } \\
\hline $\begin{array}{l}\text { Johansson, } \\
\text { 2012, Sweden }{ }^{20}\end{array}$ & $\begin{array}{l}\text { Observational, } \\
\text { pre-study }\end{array}$ & $\begin{array}{l}\text { ICU (general medical- } \\
\text { surgical) } \\
\mathrm{n}=13 \\
\text { ICU patients excluding head } \\
\text { injury, hearing impairment, } \\
\text { dementia }\end{array}$ & $\begin{array}{l}\text { A-weighted } \\
\text { decibel } \\
\text { measurements } \\
\text { Post-ICU } \\
\text { survey on } \\
\text { memories of } \\
\text { ICU } \\
\text { environment }\end{array}$ & $\begin{array}{l}\text { Delirium: hourly behavioral } \\
\text { observations by nurse based on } \\
\text { Granberg-Axell protocol (2001) and } \\
\text { DSM-IV } \\
\text { Noise: Bruel \& Kjaer } 2260 \text { sound } \\
\text { level meter placed close to patient } \\
\text { bed, one-minute average interval of } \\
\text { A-weighted sound levels analyzed } \\
\text { with B\&K Evaluator software } \\
\text { Memory survey: open-ended, } \\
\text { unstructured interview after ICU } \\
\text { discharge focusing on memories of } \\
\text { ICU environment and sounds }\end{array}$ & $\begin{array}{l}\text { No association between } \\
\text { high number of early } \\
\text { signs of ICU delirium } \\
\text { and high sound levels } \\
\text { Interview responses: } \\
\text { mixed, some sound } \\
\text { memories were } \\
\text { scary/irritating, others } \\
\text { were comforting, } \\
\text { unnoticed, or } \\
\text { incorporated into } \\
\text { dreams }\end{array}$ & $\begin{array}{l}\mathrm{p}>0.05 \text { for all sound } \\
\text { and delirium analyses } \\
\text { No statistics reported } \\
\text { for interviews. }\end{array}$ \\
\hline $\begin{array}{l}\text { Knauert, } 2016 \text {, } \\
\text { USA }^{19}\end{array}$ & $\begin{array}{l}\text { Observational, } \\
\text { prospective }\end{array}$ & $\begin{array}{l}\text { MICU } \\
\mathrm{n}=59 \\
\text { All adult patients admitted } \\
\text { within } 48 \text { hours before next } \\
\text { sound recording period, } \\
\text { excluding those expected to } \\
\text { die within } 24 \text { hours, } \\
\text { undergoing comfort care, or } \\
\text { expected to be transferred } \\
\text { before study completion }\end{array}$ & $\begin{array}{l}\text { Leq \& } \\
\text { frequency of } \\
\text { peak } \\
\text { occurrences }\end{array}$ & $\begin{array}{l}\text { Delirium: CAM-ICU daily } \\
\text { Noise: two Extech HD600 sound } \\
\text { meters placed at foot of patient bed } \\
\text { with standardized distance from } \\
\text { care equipment, } 10 \text {-second interval } \\
\text { of A- and C-weighted sound levels, } \\
\text { decibel range set to } 30-130 \mathrm{~dB}, \\
\text { detector response set to 'fast, } 125 \\
\text { milliseconds' }\end{array}$ & $\begin{array}{l}\text { Delirium was not } \\
\text { associated with Leq or } \\
\text { peak occurrences }\end{array}$ & $\begin{array}{l}\mathrm{p}>0.05 \text { for all sound } \\
\text { and delirium analyses }\end{array}$ \\
\hline \multicolumn{7}{|l|}{ Light } \\
\hline $\begin{array}{l}\text { Balan, 2001, } \\
\text { Israel }{ }^{29}\end{array}$ & $\begin{array}{l}\text { Observational, } \\
\text { retrospective }\end{array}$ & $\begin{array}{l}\text { Geriatric hospital } \\
\mathrm{n}=234 \\
\text { Patients aged } \geq 65 \text { years and } \\
\text { older, excluding patients } \\
\text { admitted with pre-existing } \\
\text { delirium or those unable to } \\
\text { communicate due to } \\
\text { cognitive impairment }\end{array}$ & $\begin{array}{l}\text { Season of } \\
\text { delirium } \\
\text { diagnosis }\end{array}$ & $\begin{array}{l}\text { Delirium: ICD-9-CM criteria, } \\
\text { assessed and diagnosed by a } \\
\text { psychiatrist after development of } \\
\text { any abrupt change in mental or } \\
\text { behavioral condition } \\
\text { Light: patients compared by season } \\
\text { of admission (winter, December- } \\
\text { February; spring, March-May; } \\
\text { summer, June-August; fall, } \\
\text { September-November) }\end{array}$ & $\begin{array}{l}\text { Significantly higher } \\
\text { rates of delirium in } \\
\text { winter than summer } \\
\text { months }\end{array}$ & $\begin{array}{l}X^{2}, 2 d f=14.36 \\
p<0.001\end{array}$ \\
\hline
\end{tabular}




\begin{tabular}{|c|c|c|c|c|c|c|}
\hline $\begin{array}{l}\text { Kohn, 2013, } \\
\text { USA }{ }^{30}\end{array}$ & $\begin{array}{l}\text { Observational, } \\
\text { retrospective }\end{array}$ & $\begin{array}{l}\text { MICU } \\
\mathrm{n}=6336 \\
\text { All admitted patients, } \\
\text { restricted to the index ICU } \\
\text { admission during a } \\
\text { hospitalization } \\
\text { SICU } \\
\mathrm{n}=6660 \\
\begin{array}{l}\text { All admitted patients, } \\
\text { restricted to the index ICU } \\
\text { admission during a } \\
\text { hospitalization }\end{array}\end{array}$ & $\begin{array}{l}\text { Presence of a } \\
\text { window } \\
\text { Whether view } \\
\text { out window was } \\
\text { a natural or } \\
\text { industrial view } \\
\text { Presence of a } \\
\text { half- or full- } \\
\text { sized window } \\
\text { for windows } \\
\text { facing the same } \\
\text { direction }\end{array}$ & $\begin{array}{l}\text { Delirium, MICU: retrospective chart } \\
\text { review of random patient sample } \\
\text { ( } 7 \% \text { ); diagnosed if specific } \\
\text { keywords associated with delirium } \\
\text { were documented by physician or } \\
\text { nurse on at least } 2 \text { separate days } \\
\text { Delirium, SICU: screened daily by } \\
\text { nurse practitioner for pre-specified } \\
\text { criteria based on new and rapid } \\
\text { onset of disturbed consciousness } \\
\text { and/or perceptual disturbance } \\
\text { Windows, both units: whether } \\
\text { patient was admitted to room with } \\
\text { or without a window; whether } \\
\text { window had a natural or industrial } \\
\text { view; whether window was half- or } \\
\text { full-sized }\end{array}$ & $\begin{array}{l}\text { No association with } \\
\text { delirium incidence and } \\
\text { the presence of a } \\
\text { window, in all analyses } \\
\text { No association with } \\
\text { delirium incidence and } \\
\text { a natural or industrial } \\
\text { view, in all analyses } \\
\text { No association between } \\
\text { delirium incidence and } \\
\text { presence of a half- or } \\
\text { full-sized window for } \\
\text { windows facing the } \\
\text { same direction, in all } \\
\text { analyses }\end{array}$ & $\begin{array}{l}\mathrm{p}>0.05 \text { for all light } \\
\text { and delirium analyses }\end{array}$ \\
\hline $\begin{array}{l}\text { Simons, 2014, } \\
\text { Netherlands }\end{array}$ & $\begin{array}{l}\text { Observational, } \\
\text { retrospective }\end{array}$ & $\begin{array}{l}\text { ICU } \\
\mathrm{n}=3198 \\
\text { All patients who were } \\
\text { admitted to the ICU within } \\
30 \text { days of hospital } \\
\text { admission, restricted to the } \\
\text { first ICU admission during a } \\
\text { hospitalization }\end{array}$ & $\begin{array}{l}\text { 7-, 28-, and 60- } \\
\text { day prehospital } \\
\text { photoperiod } \\
\text { Season of } \\
\text { admission } \\
\text { Subgroup } \\
\text { analysis: } 28 \text {-day } \\
\text { photoperiod in } \\
\text { patients } \\
\text { admitted to ICU } \\
\text { within } 48 \text { hours } \\
\text { of hospital } \\
\text { admission }\end{array}$ & $\begin{array}{l}\text { Delirium: Dutch validated CAM- } \\
\text { ICU at least twice daily during } \\
\text { complete ICU stay } \\
\text { Light: sunlight data was obtained } \\
\text { from nearby weather stations of the } \\
\text { Royal Dutch Meteorological } \\
\text { Institute; cumulative photoperiod } \\
\text { was calculated from the total } \\
\text { amount of radiation, defined as total } \\
\text { number of hours of daylight for } 7 \text {, } \\
28 \text {, and } 60 \text { days before hospital } \\
\text { admission }\end{array}$ & $\begin{array}{l}\text { No association between } \\
\text { delirium incidence and } \\
\text { prehospital sunlight } \\
\text { exposure for all } \\
\text { photoperiods (7-, 28-, } \\
60 \text {-day) } \\
\text { No association between } \\
\text { delirium incidence and } \\
\text { season of admission } \\
\text { Subgroup analysis: no } \\
\text { association between 28- } \\
\text { day photoperiod and } \\
\text { delirium incidence }\end{array}$ & $\begin{array}{l}\mathrm{p}>0.05 \text { for all light, } \\
\text { season, and delirium } \\
\text { analyses }\end{array}$ \\
\hline $\begin{array}{l}\text { Smonig, 2019, } \\
\text { France } 32\end{array}$ & $\begin{array}{l}\text { Observational, } \\
\text { prospective }\end{array}$ & $\begin{array}{l}\text { MICU } \\
\mathrm{n}=195 \\
\text { Consecutive adult patients } \\
\text { requiring invasive MV in } \\
\text { the ICU for at least } 2 \text { days, } \\
\text { without acute brain injury or }\end{array}$ & $\begin{array}{l}\text { Presence of a } \\
\text { window }\end{array}$ & $\begin{array}{l}\text { Delirium: RASS followed by } \\
\text { ICDSC twice daily, defined as the } \\
\text { presence of ICDSC } \geq 4 \text { for at least } 2 \\
\text { consecutive ICU days } \\
\text { Light: exposure determined by } \\
\text { whether patient was assigned to a } \\
\text { room with or without windows }\end{array}$ & $\begin{array}{l}\text { No association between } \\
\text { exposure to windows } \\
\text { and delirium burden } \\
\text { (incidence and } \\
\text { duration), even when } \\
\text { excluding room } \\
\text { transfers }\end{array}$ & $\begin{array}{l}\mathrm{p}>0.05 \text { for all light } \\
\text { and delirium analyses }\end{array}$ \\
\hline
\end{tabular}




\begin{tabular}{|c|c|c|c|c|c|c|}
\hline & & $\begin{array}{l}\text { conditions interfering with } \\
\text { delirium assessment (i.e. } \\
\text { dementia, deaf, blind) }\end{array}$ & & & & \\
\hline $\begin{array}{l}\text { van Rompaey, } \\
2009 \text {, Belgium } \\
13\end{array}$ & $\begin{array}{l}\text { Observational, } \\
\text { prospective }\end{array}$ & $\begin{array}{l}\text { ICU (mixed) } \\
\mathrm{n}=523 \\
\text { All consecutive patients } \\
\text { aged } \geq 18 \text { years with ICU } \\
\text { stay of } \geq 24 \text { hours; patients } \\
\text { were enrolled when GCS } \\
\text { reached at least } 10 \text {. }\end{array}$ & $\begin{array}{l}\text { Absence of } \\
\text { visible daylight }\end{array}$ & $\begin{array}{l}\text { Delirium: NEECHAM Confusion } \\
\text { Scale (frequency not specified) } \\
\text { Light: exposure determined by } \\
\text { whether patient was exposed to } \\
\text { visible daylight during ICU stay }\end{array}$ & $\begin{array}{l}\text { Patients had a } \\
\text { significantly higher risk } \\
\text { of developing delirium } \\
\text { with the absence of } \\
\text { visible daylight }\end{array}$ & $\begin{array}{l}\text { Univariate } \\
\text { OR } 1.75 \\
95 \% \text { CI }(1.19-2.56) \\
\mathrm{p}=0.003 \\
\text { Multivariate } \\
\text { OR 2.39 } \\
\text { 95\% CI }(1.28-4.45)\end{array}$ \\
\hline \multicolumn{7}{|l|}{ Sleep } \\
\hline $\begin{array}{l}\text { Boesen, 2016, } \\
\text { Denmark }^{33}\end{array}$ & $\begin{array}{l}\text { Observational, } \\
\text { prospective } \\
\text { descriptive }\end{array}$ & $\begin{array}{l}\text { ICU (mixed) } \\
\mathrm{n}=14 \\
\text { Mechanically ventilated } \\
\text { patients } \geq 18 \text { years, without } \\
\text { structural neurological } \\
\text { illnesses or administration } \\
\text { of propofol or } \\
\text { benzodiazepines }\end{array}$ & $\begin{array}{l}\text { PSG results } \\
\text { Sleep as } \\
\text { recorded by } \\
\text { CBO }\end{array}$ & $\begin{array}{l}\text { Delirium: SAS \& CAM-ICU once } \\
\text { per shift } \\
\text { Sleep, PSG: } 24 \text { hour simplified PSG } \\
\text { with a 2-lead-frontal EEG (no } \\
\text { occipital or central leads), 2-lead } \\
\text { EOG, } 1 \text { chin EMG, and 1-lead } \\
\text { ECG; G\&B Electronic Designs Ltd: } \\
\text { Lifelines, TrackIT screener PP3-S; } \\
\text { recording started at noon; PSGs } \\
\text { were scored by an EEG technician } \\
\text { in } 30 \text { second epochs according to } \\
\text { the AASM standards; atypical PSGs } \\
\text { were re-scored; due to } \\
\text { encephalopathy, wakefulness was } \\
\text { interpreted using eye-blinking and } \\
\text { EEG reactivity } \\
\text { Sleep, CBO: } 24 \text { hour clinical sleep } \\
\text { registration done by attending } \\
\text { nurses, noted on a case report form } \\
\text { as "asleep" or "awake"; awakenings } \\
\text { were registered as transitions from } \\
\text { "asleep" to "awake"; measurements } \\
\text { included total clinical time awake, } \\
\text { total clinical time asleep, and } \\
\text { number of hours with logged entries }\end{array}$ & $\begin{array}{l}\text { No clear differences in } \\
\text { sleep patterns between } \\
\text { patients with and } \\
\text { without delirium, for } \\
\text { both PSG and CBO } \\
\text { analysis } \\
\text { The more pathological } \\
\text { the EEGs and the } \\
\text { patients were, the less } \\
\text { correlation with } \\
\text { clinically observed } \\
\text { sleep was seen } \\
\text { Sleep quality and } \\
\text { quantity cannot be } \\
\text { feasibly assessed with } \\
\text { PSG in mechanically } \\
\text { ventilated ICU patients, } \\
\text { since the vast majority } \\
\text { of PSGs were atypical } \\
\text { without objective sleep } \\
\text { signs }\end{array}$ & $\begin{array}{l}\mathrm{p}>0.05 \text { for all sleep } \\
\text { and delirium analyses }\end{array}$ \\
\hline $\begin{array}{l}\text { Bowman, 1997, } \\
\text { Canada }^{34}\end{array}$ & $\begin{array}{l}\text { Observational, } \\
\text { descriptive }\end{array}$ & $\begin{array}{l}\text { Teaching hospital } \\
\mathrm{n}=43 \\
\text { Elderly subjects undergoing } \\
\text { orthopedic hip surgery (age }\end{array}$ & $\begin{array}{l}\text { Sleep } \\
\text { satisfaction }\end{array}$ & $\begin{array}{l}\text { Delirium: DSM-III diagnosis as } \\
\text { evidenced by notes in RN reports, } \\
\text { chart review, interview with on-duty } \\
\text { RNs, or assessment by researcher } \\
\text { during researcher's daily rounds; }\end{array}$ & $\begin{array}{l}\text { Patients who developed } \\
\text { post-operative delirium } \\
\text { had poorer sleep } \\
\text { satisfaction than those } \\
\text { without post-operative }\end{array}$ & $\begin{array}{l}\text { Day } 2 \\
p=0.008574 \\
\text { Day } 3 \\
p=0.031772\end{array}$ \\
\hline
\end{tabular}




\begin{tabular}{|c|c|c|c|c|c|c|}
\hline & & $\begin{array}{l}\text { criteria not specified); } \\
\text { subjects with known } \\
\text { dementia or MMSE score } \leq \\
23 \text { were excluded }\end{array}$ & & $\begin{array}{l}\text { MMSE repeated daily until subject } \\
\text { obtained score of } \geq 24 \\
\text { Sleep: previous night's sleep } \\
\text { satisfaction recorded every AM for } \\
5 \text { days using a seven-point Likert } \\
\text { scale }\end{array}$ & $\begin{array}{l}\text { delirium, except } \\
\text { postoperative day } 5\end{array}$ & $\begin{array}{l}\mathrm{p}>0.05 \text { for all other } \\
\text { sleep and delirium } \\
\text { analyses }\end{array}$ \\
\hline $\begin{array}{l}\text { Drouot, 2012, } \\
\text { France }^{35}\end{array}$ & $\begin{array}{l}\text { Observational, } \\
\text { retrospective }\end{array}$ & $\begin{array}{l}\text { MICU } \\
\text { n=57 } \\
\text { Adult, conscious, non- } \\
\text { sedated ICU patients } \\
\text { admitted for acute } \\
\text { respiratory failure \& treated } \\
\text { with NIV for at least } 2 \text { days, } \\
\text { without presence of: CNS } \\
\text { disorder, GCS }<15 \text {, } \\
\text { delirium and/or confusion, } \\
\text { administration in past } 2 \text { days } \\
\text { of drugs interfering with } \\
\text { sleep \& EEG activity }\end{array}$ & PSG results & $\begin{array}{l}\text { Delirium: CAM-ICU daily } \\
\text { Sleep: Embla S700 digital recorder } \\
\text { from } 1500 \text { to } 0800 \text { on the following } \\
\text { day; leads included: three EEG } \\
\text { channels, chin EMG, two EOGs, } \\
\text { submental EMG, two tibialis } \\
\text { anterior EMGs, and ECG; EEG } \\
\text { signals amplified and recorded at } \\
200-H z \text { sampling frequency, filtered } \\
(0.5-70 \mathrm{~Hz}) \text {; Rechtschaffen and } \\
\text { Kales criteria were used to score } \\
\text { sleep stages and awakenings }\end{array}$ & $\begin{array}{l}\text { Significant association } \\
\text { between delirium } \\
\text { occurrence and atypical } \\
\text { sleep on EEG }\end{array}$ & $\mathrm{p}<0.05$ \\
\hline $\begin{array}{l}\text { Kamdar, 2015, } \\
\text { USA }^{36}\end{array}$ & $\begin{array}{l}\text { Secondary } \\
\text { analysis of } \\
\text { prospective } \\
\text { observational } \\
\text { study }\end{array}$ & $\begin{array}{l}\text { MICU } \\
\mathrm{n}=223 \\
\text { Patients with } \geq 1 \text { night in the } \\
\text { MICU in between two } \\
\text { consecutive days of } \\
\text { delirium assessment, data } \\
\text { analysis was only on } \\
\text { patients' first MICU } \\
\text { admission }\end{array}$ & $\begin{array}{l}\text { Perceived sleep } \\
\text { quality }\end{array}$ & $\begin{array}{l}\text { Delirium: CAM-ICU twice daily at } \\
0800 \text { and } 2000 \\
\text { Sleep: RCSQ daily with an } \\
\text { additional item to evaluate } \\
\text { perceived night-time noise }\end{array}$ & $\begin{array}{l}\text { No association between } \\
\text { transition to delirium } \\
\text { and perceived sleep } \\
\text { quality }\end{array}$ & $\begin{array}{l}\mathrm{p}>0.05 \text { for all sleep } \\
\text { and delirium analyses }\end{array}$ \\
\hline $\begin{array}{l}\text { Kaneko, 1997, } \\
\text { Japan }{ }^{37}\end{array}$ & Observational & $\begin{array}{l}\mathrm{HCU} \\
\mathrm{n}=36 \\
\text { Patients aged over } 70 \text { years } \\
\text { undergoing gastrointestinal } \\
\text { surgery }\end{array}$ & $\begin{array}{l}\text { Sleep-cycle } \\
\text { disturbances }\end{array}$ & $\begin{array}{l}\text { Delirium: DSM-III-R (frequency } \\
\text { not specified) } \\
\text { Sleep: clinical behavioral } \\
\text { observations on sleep \& } \\
\text { wakefulness recorded in two blocks } \\
\text { (daytime, 0600-1800; night-time } \\
\text { 1800-0600) }\end{array}$ & $\begin{array}{l}\text { Postoperative abnormal } \\
\text { sleep patterns are } \\
\text { significantly associated } \\
\text { with development of } \\
\text { delirium }\end{array}$ & $\mathrm{p}<0.05$ \\
\hline $\begin{array}{l}\text { Knauert, 2014, } \\
\text { USA }^{38}\end{array}$ & $\begin{array}{l}\text { Observational, } \\
\text { cross-section } \\
\text { pilot }\end{array}$ & $\begin{array}{l}\text { MICU } \\
n=29\end{array}$ & $\begin{array}{l}\text { Atypical sleep } \\
\text { on PSG }\end{array}$ & $\begin{array}{l}\text { Delirium: CAM-ICU on day of } \\
\text { enrollment and during PSG } \\
\text { (frequency not specified) }\end{array}$ & $\begin{array}{l}\text { No significant } \\
\text { relationship between } \\
\text { delirium incidence and } \\
\text { atypical sleep }\end{array}$ & $\begin{array}{l}\mathrm{p}>0.05 \text { for all sleep } \\
\text { and delirium analyses }\end{array}$ \\
\hline
\end{tabular}




\begin{tabular}{|c|c|c|c|c|c|c|}
\hline & & $\begin{array}{l}\text { Adults admitted to the } \\
\text { MICU for less than } 72 \text { hours } \\
\text { without terminal illness, } \\
\text { coma or deep sedation, } \\
\text { severe agitation, or } \\
\text { anatomic contraindications } \\
\text { to PSG evaluation }\end{array}$ & & $\begin{array}{l}\text { Sleep: unattended PSG for up to } 24 \\
\text { hours via Compumedics' Safiro } \\
\text { Portable Data Acquisition System; } \\
\text { initiated in the evening; leads } \\
\text { included: } 6 \text { EEG channels, chin } \\
\text { EMG, right and left EOG; ECG; } \\
200 \mathrm{~Hz} \text { sampling frequency and } \\
\text { filtered (0.5 - } 70 \mathrm{~Hz} \text { ); } \\
\text { Compumedics' Profusion } 2 \\
\text { software; if no stage could be } \\
\text { marked, the epoch was marked } \\
\text { 'unsure'; if epoch could be } \\
\text { identified as sleep, but stage was } \\
\text { unclear, it was marked 'sleep (no } \\
\text { stage)' }\end{array}$ & & \\
\hline $\begin{array}{l}\text { Kumar, } 2017, \\
\text { India }^{39}\end{array}$ & $\begin{array}{l}\text { Observational, } \\
\text { pilot } \\
\text { prospective } \\
\text { derivation } \\
\text { cohort }\end{array}$ & $\begin{array}{l}\text { SICU (cardiac) } \\
\mathrm{n}=120 \\
\text { consecutive adult patients } \\
\text { undergoing elective or } \\
\text { emergency cardiac surgery } \\
\text { without preexisting delirium } \\
\text { or deafness }\end{array}$ & $\begin{array}{l}\text { Sleep } \\
\text { deprivation }\end{array}$ & $\begin{array}{l}\text { Delirium: assessed once daily with } \\
\text { RASS followed by CAM-ICU } \\
\text { starting on day of extubation } \\
\text { Sleep: method of measurement not } \\
\text { specified }\end{array}$ & $\begin{array}{l}\text { Sleep deprivation was } \\
\text { not significantly related } \\
\text { to delirium }\end{array}$ & $\begin{array}{l}\mathrm{p}>0.05 \text { for all sleep } \\
\text { and delirium analyses }\end{array}$ \\
\hline $\begin{array}{l}\text { Shigeta, 2001, } \\
\text { Japan } 40\end{array}$ & Observational & $\begin{array}{l}\text { General hospital } \\
\mathrm{n}=29 \\
\text { Patients undergoing } \\
\text { laparotomy for digestive } \\
\text { disease }\end{array}$ & $\begin{array}{l}\text { Sleep } \\
\text { disturbances }\end{array}$ & $\begin{array}{l}\text { Delirium: CAM followed by DSM- } \\
\text { IV diagnosis } \\
\text { Sleep: subjects' sleep was } \\
\text { monitored every } 2 \text { hours for } 5 \text { days } \\
\text { after surgery }\end{array}$ & $\begin{array}{l}\text { All patients with } \\
\text { delirium showed sleep } \\
\text { disturbances with } \\
\text { reversal of the diurnal } \\
\text { sleep cycle, including } \\
\text { delayed sleep onset, } \\
\text { frequent waking, and } \\
\text { increased daytime sleep } \\
\text { on the following day }\end{array}$ & No statistics reported. \\
\hline $\begin{array}{l}\text { Trompeo, 2011, } \\
\text { Italy } 41\end{array}$ & Observational & $\begin{array}{l}\text { ICU } \\
\text { n=29 } \\
\text { Patients aged } 18-75 \text { with } \\
\text { MV for at least } 2 \text { days for } \\
\text { acute respiratory failure } \\
\text { related to surgery, excluding } \\
\text { chronic dementia, } \\
\text { psychosis, mental } \\
\text { retardation, stroke, } \\
\text { Alzheimer disease, } \\
\text { Parkinson disease, central }\end{array}$ & PSG results & $\begin{array}{l}\text { Delirium: CAM-ICU twice daily } \\
\text { Sleep: NPB-Mallinckrodt Sandman } \\
\text { PSG done from } 2200-0800 \text {, scored } \\
\text { using Rechtschaffen and Kales } \\
\text { criteria }\end{array}$ & $\begin{array}{l}\text { Delirium is } \\
\text { independently } \\
\text { associated with severe } \\
\text { REM sleep reduction }\end{array}$ & $\mathrm{p}=0.002$ \\
\hline
\end{tabular}




\begin{tabular}{|c|c|c|c|c|c|c|}
\hline & & $\begin{array}{l}\text { sleep apnea, drug or alcohol } \\
\text { abuse }\end{array}$ & & & & \\
\hline $\begin{array}{l}\text { Whitcomb, } \\
\text { 2013, USA }\end{array}$ & $\begin{array}{l}\text { Observational, } \\
\text { pilot }\end{array}$ & $\begin{array}{l}\text { MICU (pulmonary) } \\
\mathrm{n}=7 \\
65 \text { years or older, intubated } \\
\& \text { sedated without a } \\
\text { diagnosis preventing mental } \\
\text { awareness assessment }\end{array}$ & Sleep stages & $\begin{array}{l}\text { Delirium: ICDSC once daily } \\
\text { Sleep: Zeo wireless sleep monitor, } \\
\text { dry silver-coated fabric headband } \\
\text { sensor with single bipolar channel, } \\
\text { signal includes EEG/EOG/EMG, } \\
\text { captured at } 128 \text { samples per second } \\
\text { and filtered to a frequency of } 2 \text { to } 47 \\
\text { Hz, microprocessor reports the sleep } \\
\text { stage every } 30 \text { seconds in real time } \\
\text { via artificial neural network using a } \\
\text { reduced set of sleep stages including } \\
\text { wakefulness, REM sleep, light sleep } \\
\text { (combined stages } 1 \text { and } 2 \text { ), and deep } \\
\text { sleep (combined stages } 3 \text { and } 4 \text { ) }\end{array}$ & $\begin{array}{l}\text { Preliminary results } \\
\text { suggest a relationship } \\
\text { between lack of REM } \\
\text { sleep and delirium }\end{array}$ & No statistics reported. \\
\hline $\begin{array}{l}\text { Yildizeli, 2005, } \\
\text { Turkey } 43\end{array}$ & $\begin{array}{l}\text { Observational, } \\
\text { retrospective }\end{array}$ & $\begin{array}{l}\text { General hospital } \\
\mathrm{n}=432 \\
\text { All patients older than } 18 \\
\text { years who were admitted for } \\
\text { thoracotomy or sternotomy } \\
\text { with an expected stay of } 2 \\
\text { or more days }\end{array}$ & $\begin{array}{l}\text { Sleep } \\
\text { deprivation }\end{array}$ & $\begin{array}{l}\text { Delirium: once delirium symptoms } \\
\text { were first noted, a psychiatric } \\
\text { consult determined diagnosis based } \\
\text { on DSM-IV criteria } \\
\text { Sleep: method of measurement not } \\
\text { specified }\end{array}$ & $\begin{array}{l}\text { Univariate and } \\
\text { multivariate analyses } \\
\text { showed a significant } \\
\text { association between } \\
\text { delirium incidence and } \\
\text { sleep deprivation }\end{array}$ & $\begin{array}{l}\text { Univariate } \\
p=0.008 \\
\text { Multivariate } \\
\text { OR 5.642 } \\
p=0.05\end{array}$ \\
\hline $\begin{array}{l}\text { Zhang, 2015, } \\
\text { China }{ }^{44}\end{array}$ & $\begin{array}{l}\text { Observational, } \\
\text { prospective } \\
\text { cohort }\end{array}$ & $\begin{array}{l}\text { ICU (cardiovascular) } \\
\text { n=249 } \\
\text { adult, post-CABG patients } \\
\text { without preoperative } \\
\text { diagnoses of delirium, } \\
\text { mental disease, or dementia }\end{array}$ & Quality of sleep & $\begin{array}{l}\text { Delirium: assessed three times daily } \\
(0800,1600,2400) \text { with RASS } \\
\text { followed by CAM-ICU, and if } \\
\text { patient developed change in mental } \\
\text { status } \\
\text { Sleep quality: assessed via patient } \\
\text { self-report, poor quality was defined } \\
\text { by symptoms of sleep disorder or } \\
\text { sleep deprivation }\end{array}$ & $\begin{array}{l}\text { Poor sleep quality was } \\
\text { the strongest } \\
\text { independent predictor } \\
\text { of delirium }\end{array}$ & $\begin{array}{l}\text { Univariate } \\
\mathrm{p}<0.001 \\
\text { Multivariate } \\
\text { OR 5.001 } \\
95 \% \text { CI }(2.476-10.101) \\
\mathrm{p}<0.0001\end{array}$ \\
\hline \multicolumn{7}{|c|}{ Multiple Factors } \\
\hline $\begin{array}{l}\text { Davoudi, 2019, } \\
\text { USA }^{45}\end{array}$ & $\begin{array}{l}\text { Observational, } \\
\text { prospective } \\
\text { pilot }\end{array}$ & $\begin{array}{l}\text { SICU } \\
\mathrm{n}=22 \\
\text { All adult patients expected } \\
\text { to stay in ICU more than } 2 \\
\text { day and able to wear an } \\
\text { ActiGraph device }\end{array}$ & $\begin{array}{l}\text { Sound pressure } \\
\text { levels } \\
\text { Light intensity } \\
\text { Sleep quality }\end{array}$ & $\begin{array}{l}\text { Delirium: CAM-ICU daily, defined } \\
\text { as being delirious throughout study } \\
\text { period } \\
\text { Noise: iPod with a sound pressure } \\
\text { recording application measured in } \\
\text { dB, device placed on wall behind } \\
\text { patient bed }\end{array}$ & $\begin{array}{l}\text { Average night-time } \\
\text { sound pressure levels } \\
\text { were significantly } \\
\text { higher in delirious } \\
\text { patients } \\
\text { Light levels were } \\
\text { significantly different }\end{array}$ & $\begin{array}{l}\text { Sound } \\
\mathrm{p}<0.05 \\
\text { Light } \\
\mathrm{p}<0.05 \\
\text { Ability to fall asleep } \\
\mathrm{p}=0.01\end{array}$ \\
\hline
\end{tabular}




\begin{tabular}{|c|c|c|c|c|c|c|}
\hline & & & & $\begin{array}{l}\text { Light: ActiGraph sensor placed on } \\
\text { wall behind patient bed at height of } \\
\text { patient head } \\
\text { Sleep: Freedman Sleep } \\
\text { Questionnaire daily }\end{array}$ & $\begin{array}{l}\text { between delirious and } \\
\text { non-delirious patients } \\
\text { No statistical } \\
\text { association between } \\
\text { overall quality of sleep } \\
\text { and delirium, but } \\
\text { delirious patients were } \\
\text { significantly more } \\
\text { likely to report } \\
\text { difficulty falling asleep } \\
\text { and to find lighting } \\
\text { disruptive at night }\end{array}$ & $\begin{array}{l}\text { Whether night-time } \\
\text { lighting was disruptive } \\
\mathrm{p}=0.04 \\
\mathrm{p}>0.05 \text { for all other } \\
\text { sleep and delirium } \\
\text { analyses }\end{array}$ \\
\hline $\begin{array}{l}\text { Simeone, 2018, } \\
\text { Italy } 46\end{array}$ & \begin{tabular}{|l|} 
Observational, \\
correlational
\end{tabular} & $\begin{array}{l}\text { SICU (cardiac) } \\
\mathrm{n}=89 \\
\text { All patients aged } \geq 18 \text { years } \\
\text { who underwent cardiac } \\
\text { surgery with ICU stay } \\
\text { longer than } 24 \text { hours, } \\
\text { excluding history of } \\
\text { psychologic disease or } \\
\text { psychogenic drug use, } \\
\text { visual disturbances, hearing } \\
\text { disorder, RASS } \leq 4\end{array}$ & $\begin{array}{l}\text { Exposure to } \\
\text { natural sunlight } \\
\text { Presence of a } \\
\text { sleep disorder }\end{array}$ & $\begin{array}{l}\text { Delirium: RASS followed by CAM- } \\
\text { ICU } \\
\text { Light: whether patient was exposed } \\
\text { to natural sunlight } \\
\text { Sleep: whether patient has pre- } \\
\text { existing sleep disorder }\end{array}$ & $\begin{array}{l}\text { Significantly more } \\
\text { patients with delirium } \\
\text { were not in a location } \\
\text { with sunlight } \\
\text { Significantly more } \\
\text { patients with delirium } \\
\text { had a sleep disorder }\end{array}$ & $\begin{array}{l}\text { Light, univariate } \\
X^{2}=9.737 \\
\mathrm{p}=0.32 \\
\text { Light, multivariate } \\
\text { RRR 0.367 } \\
95 \% \text { CI }(0.090-1.494) \mathrm{p} \\
=0.034 \\
\text { Sleep, univariate } \\
X^{2}=13.934 \\
\mathrm{p}<0.001 \\
\text { Sleep, multivariate } \\
\text { RRR 5.493 } \\
95 \% \text { CI }(1.255-24.047) \\
\mathrm{p}=0.024\end{array}$ \\
\hline
\end{tabular}

Abbreviations: AASM: American Academy of Sleep Medicine; CABG: coronary artery bypass graft; CAM-ICU: Confusion Assessment Method for the Intensive Care Unit; CBO: clinical behavioral observation; CI: confidence interval; CNS: central nervous system; dB: decibel; df: degrees of freedom; DSM-III: Diagnostic and Statistical Manual of Mental Disorders, 3rd Edition; DSM-III-R: Diagnostic and Statistical Manual of Mental Disorders, 3rd Edition, Revised; DSM-IV: Diagnostic and Statistical Manual of Mental Disorders, 4th Edition; ECG: electrocardiography; EEG: electroencephalography; EMG: electromyography; EOG: electrooculography; GCS: Glasgow Coma Scale; HCU: high intensive care unit; ICD-9-CM: International Classification of Diseases, Ninth Revision, Clinical Modification; ICDSC: Intensive Care Delirium Screening Checklist; ICU: intensive care unit; Leq: equivalent continuous sound pressure level; MICU: medical intensive care unit; MMSE: Mini-Mental State Examination; MV: mechanical ventilation; NEECHAM: Neelon and Champagne Confusion Scale; NIV: non-invasive ventilation; OR: odds ratio; PSG: polysomnography; RASS: Richmond Agitation and Sedation Scale; RCSQ: Richards-Campbell Sleep Questionnaire; REM: rapid eye movement; RRR: relative risk ratio; SAS: Riker Sedation-Agitation Scale; SICU: surgical intensive care unit; X²: chi-squared test. 
Table 2. Summary of Characteristics and Findings of Reviewed Interventional Studies

\begin{tabular}{|c|c|c|c|c|c|c|}
\hline $\begin{array}{c}\text { Study } \\
\text { (Author, } \\
\text { Year, } \\
\text { Country) }\end{array}$ & $\begin{array}{c}\text { Study } \\
\text { Purpose }\end{array}$ & $\begin{array}{l}\text { Study } \\
\text { Design }\end{array}$ & $\begin{array}{c}\text { Study Setting } \\
\text { Population } \\
\text { Subjects Characteristics }\end{array}$ & Intervention Details & $\begin{array}{c}\text { Outcomes }^{1} \text { (Methods of } \\
\text { Assessment) }\end{array}$ & Findings \\
\hline \multicolumn{7}{|c|}{ Architectural design modification } \\
\hline $\begin{array}{l}\text { Johansson, } \\
2018, \\
\text { Sweden }{ }^{18}\end{array}$ & $\begin{array}{l}\text { To assess } \\
\text { feasibility and } \\
\text { effect of a } \\
\text { modified ICU } \\
\text { room on noise } \\
\text { and delirium }\end{array}$ & $\begin{array}{l}\text { Quasi RCT } \\
\text { (feasibility } \\
\text { study) }\end{array}$ & $\begin{array}{l}\text { ICU (General) } \\
\mathrm{n}=31: 25 \text { control, } 6 \\
\text { intervention } \\
\text { Adult, ICU stay } \geq 48 \mathrm{hrs}\end{array}$ & $\begin{array}{l}\text { Modified ICU room to } \\
\text { control noise: Installed drop } \\
\text { ceilings with low frequency } \\
\text { noise absorber, plain room } \\
\text { design, kept mobile medical } \\
\text { equipment in room only if } \\
\text { required } \\
\text { Control group: same ICU } \\
\text { room with no modification }\end{array}$ & $\begin{array}{l}\text { Delirium prevalence(CAM- } \\
\text { ICU) } \\
\text { Level of noise (Microphone } \\
\text { located } 10 \mathrm{~cm} \text { below ceiling, } \\
\text { and } 130-160 \mathrm{~cm} \text { from wall, } \\
\text { attached to a sound-card, } \\
\text { recorded } 30 \mathrm{~s} \text { intervals of A, C, } \\
\text { and } \mathrm{Z} \text { weighted noise levels) }\end{array}$ & 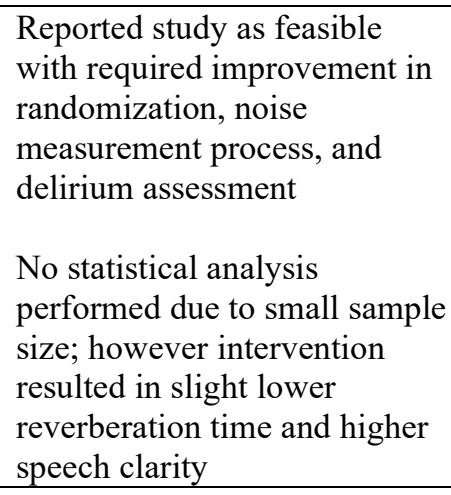 \\
\hline $\begin{array}{l}\text { Zaal, 2013, } \\
\text { Netherlands } \\
47\end{array}$ & $\begin{array}{l}\text { To explore } \\
\text { effect of ICU } \\
\text { environment } \\
\text { on incidence, } \\
\text { and course of } \\
\text { delirium }\end{array}$ & \begin{tabular}{|l|} 
Pre- post \\
Intervention
\end{tabular} & 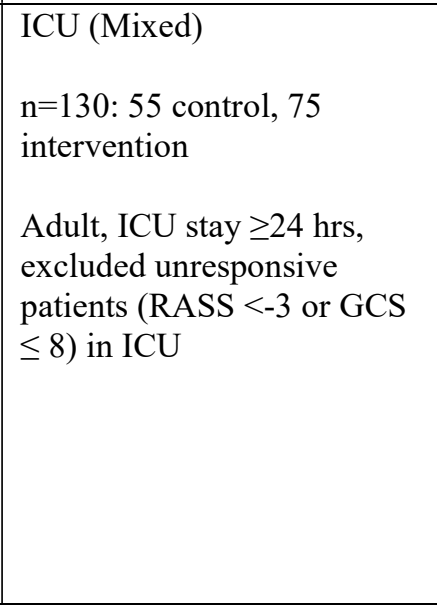 & $\begin{array}{l}\text { Single-bed room ICU with } \\
\text { more daylight and less } \\
\text { noise exposure: Use of } \\
\text { sound absorbers, glass } \\
\text { sliding doors, optimized } \\
\text { alarm system sending } \\
\text { filtered alarms to staff cell } \\
\text { phones, remotely controlled } \\
\text { monitors, sufficient daylight } \\
\text { with view, warm colored } \\
\text { room design } \\
\text { Control group: multi-bed } \\
\text { room, beds separated by } \\
\text { curtains }\end{array}$ & $\begin{array}{l}\text { Delirium incidence, and } \\
\text { duration (CAM-ICU) } \\
\text { Delirium severity (non- } \\
\text { validated DSI) } \\
\text { Level of light (Light-sensor } \\
\text { placed 1m from bed's head, } \\
\text { recorded 30s intervals of light } \\
\text { intensity in Volts) }\end{array}$ & $\begin{array}{l}\text { No significant effect on } \\
\text { incidence of delirium } \\
\text { Decreased number of days } \\
\text { with delirium } \\
\text { No effect on severity of } \\
\text { delirium } \\
\text { Increased daylight exposure, } \\
\text { but no effect on night-time } \\
\text { light exposure }\end{array}$ \\
\hline \multicolumn{7}{|c|}{ Noise modification interventions } \\
\hline $\begin{array}{l}\text { van de Pol, } \\
2017, \\
\text { Netherlands } \\
14\end{array}$ & $\begin{array}{l}\text { To test effect } \\
\text { of nocturnal } \\
\text { sound- } \\
\text { reduction } \\
\text { protocol on } \\
\text { delirium } \\
\text { incidence and } \\
\text { sleep quality in } \\
\text { ICU }\end{array}$ & \begin{tabular}{|l|} 
Pre- post \\
Intervention \\
(interrupted \\
time series)
\end{tabular} & $\begin{array}{l}\text { ICU (Medical and Surgical) } \\
\text { n=421: } 211 \text { control, } 210 \\
\text { intervention } \\
\text { Adult, non-delirious, } \\
\text { RASS }<-3 \text { for }>50 \% \text { of ICU } \\
\text { stay, ICU stay } \geq 24 \mathrm{hrs}\end{array}$ & $\begin{array}{l}\text { Nocturnal sound-reduction } \\
\text { protocol: Lowered staff and } \\
\text { devices noise, clustered } \\
\text { care-activities, closed doors } \\
\text { and earplugs in non- } \\
\text { delirious patients, limited } \\
\text { and clustered care activities } \\
\text { Control group: usual care }\end{array}$ & $\begin{array}{l}\text { Delirium incidence (ICDSC) } \\
\text { Sleep (RCSQ) } \\
\text { Level of noise (Perceived noise } \\
\text { item of RCSQ, and Sound } \\
\text { meter with microphone located } \\
\text { near bed's head, recorded 1s }\end{array}$ & $\begin{array}{l}\text { Decreased delirium incidence } \\
\text { No improvement in sleep } \\
\text { quality } \\
\text { Reduced perceived night-time } \\
\text { noise. Noise pressure levels } \\
\text { not compared between the two }\end{array}$ \\
\hline
\end{tabular}




\begin{tabular}{|c|c|c|c|c|c|c|}
\hline & & & & & $\begin{array}{l}\text { intervals of A weighted noise } \\
\text { levels) }\end{array}$ & $\begin{array}{l}\text { groups due to unusable pre- } \\
\text { intervention values } \\
\text { Reduced use of sleep } \\
\text { medication, no effect on } \\
\text { delirium medication }\end{array}$ \\
\hline $\begin{array}{l}\text { Van } \\
\text { Rompaey, } \\
2012, \\
\text { Belgium }{ }^{48}\end{array}$ & $\begin{array}{l}\text { To evaluate } \\
\text { effect of } \\
\text { sleeping with } \\
\text { earplugs on } \\
\text { prevention of } \\
\text { delirium in } \\
\text { ICU }\end{array}$ & RCT & $\begin{array}{l}\text { ICU (Medical, surgical, } \\
\text { cardiosurgical) } \\
\mathrm{n}=136 \text { : } 67 \text { control, } 69 \\
\text { intervention } \\
\text { Adult, non-delirious, non- } \\
\text { sedated, non-intubated, } \\
\text { GCS } \geq 10 \text {, no dementia, ICU } \\
\text { stay }>24 \text { hrs }\end{array}$ & $\begin{array}{l}\text { Earplugs during sleep from } \\
2200 \text { to } 0600 \\
\text { Control group: No earplugs }\end{array}$ & $\begin{array}{l}\text { Delirium incidence } \\
\text { (NEECHAM) } \\
\text { Sleep perception (Non- } \\
\text { validated simplified sleep } \\
\text { questionnaire with five } \\
\text { dichotomous questions) }\end{array}$ & $\begin{array}{l}\text { No effect on incidence of } \\
\text { delirium, but reduced risk of } \\
\text { confusion, and increased time } \\
\text { to cognitive disturbance onset } \\
\text { Improved sleep quality }\end{array}$ \\
\hline \multicolumn{7}{|c|}{ Light modification interventions } \\
\hline $\begin{array}{l}\text { Estrup, } \\
2018, \\
\text { Denmark }^{15}\end{array}$ & $\begin{array}{l}\text { To explore } \\
\text { delirium } \\
\text { incidence, and } \\
\text { risk factor and } \\
\text { effect of } \\
\text { circadian light } \\
\text { on delirium in } \\
\text { ICU }\end{array}$ & $\begin{array}{l}\text { Retrospectiv } \\
\text { e cohort } \\
\text { study }\end{array}$ & $\begin{array}{l}\text { ICU (Mixed medical and } \\
\text { surgical) } \\
\mathrm{n}=183 \\
\text { Adult, non-sedated patients } \\
\text { with available CAM-ICU } \\
\text { scores, without any coma: } \\
\begin{array}{l}\text { RASS of }-5 \text { or }-4 \text {, or severe } \\
\text { dementia }\end{array}\end{array}$ & $\begin{array}{l}\text { Circadian Lighting: } \\
\text { Supplemental lighting } \\
\text { system delivered light with } \\
\text { strongest intensity of } 40001 \mathrm{x} \\
\text { and most blue component } \\
\text { from } 0700 \text { to } 1200 \text {, and } \\
\text { minimum of 50lx at } 2030 \\
\text { Control group: Regular } \\
\text { lighting }\end{array}$ & $\begin{array}{l}\text { Delirium Incidence (CAM- } \\
\text { ICU, and use of Haloperidole) }\end{array}$ & $\begin{array}{l}\text { No effect on incidence of } \\
\text { delirium } \\
\text { Reported age and } \\
\text { dexedetomidine as risk factors } \\
\text { for delirium }\end{array}$ \\
\hline $\begin{array}{l}\text { Pustjens, } \\
2019, \\
\text { Netherlands } \\
49\end{array}$ & $\begin{array}{l}\text { To test effect } \\
\text { of dynamic } \\
\text { lighting on } \\
\text { delirium and }\end{array}$ & $\begin{array}{l}\text { Retrospectiv } \\
\text { e cohort } \\
\text { study }\end{array}$ & $\begin{array}{l}\text { CCU } \\
n=748: 379 \text { control, } 369 \\
\text { intervention } \\
\text { Adult non-sedated patients } \\
\text { with ICU stay of } 24 \text { hrs or } \\
\text { more }\end{array}$ & $\begin{array}{l}\text { Circadian Lighting: Ceiling } \\
\text { mounted LED panels } \\
\text { delivered light with color } \\
\text { temperature between } 2700 \\
\text { and } 6500 \mathrm{~K} \text { at varying } \\
\text { intensities (peak } 750 \mathrm{~lx} \text { ) } \\
\text { Control group: Regular } \\
\text { lighting }\end{array}$ & $\begin{array}{l}\text { Delirium incidence (DOSS, and } \\
\text { CAM) }\end{array}$ & $\begin{array}{l}\text { No effect on incidence of } \\
\text { delirium }\end{array}$ \\
\hline $\begin{array}{l}\text { Simons, } \\
2016, \\
\text { Netherlands } \\
50\end{array}$ & $\begin{array}{l}\text { To assess } \\
\text { effect of } \\
\text { dynamic } \\
\text { lighting on } \\
\text { incidence and } \\
\text { duration of } \\
\text { delirium }\end{array}$ & RCT & $\begin{array}{l}\text { ICU (Mixed medical \& } \\
\text { surgical) } \\
\text { (n=714: } 360 \text { control, } 354 \\
\text { intervention) } \\
\text { Adult, ICU stay>24 hrs, } \\
\text { both intubated and non- } \\
\text { intubaed without } \\
\text { impairments preventing }\end{array}$ & $\begin{array}{l}\text { Artificial high-intensity } \\
\text { dynamic lighting } \\
\text { application: Ceiling } \\
\text { mounted fluorescent tubes } \\
\text { delivered light with } \\
\text { alteration in color } \\
\text { temperature and intensity: } \\
\text { blueish-white light up to } \\
4300 \mathrm{~K} \text {, and } 1700 \text { lx from } \\
0900 \text { to } 1600 \text {, except }\end{array}$ & $\begin{array}{l}\text { Delirium incidence, and } \\
\text { duration (CAM-ICU) } \\
\\
\text { Level of light (Photometer } \\
\text { placed at } 2 \mathrm{~m} \text { height on wall } \\
\text { near bed's head, recorded } \\
15 \text { min intervals of light } \\
\text { intensity in lx) }\end{array}$ & $\begin{array}{l}\text { No significant effect on } \\
\text { incidence of delirium, or } \\
\text { number of delirium-free days } \\
\text { Increased mean } \\
\text { cumulative daytime lighting }\end{array}$ \\
\hline
\end{tabular}




\begin{tabular}{|c|c|c|c|c|c|c|}
\hline & & & $\begin{array}{l}\text { delirium assessments were } \\
\text { included }\end{array}$ & $\begin{array}{l}\text { intensity of } 300 \mathrm{~lx} \text { from } \\
1130 \text { to } 1330 \\
\text { Control group: Usual } \\
\text { lighting: } 300 \mathrm{~lx}, 3000 \mathrm{~K}\end{array}$ & & \\
\hline $\begin{array}{l}\text { Taguchi, } \\
\text { 2007, Japan } \\
51\end{array}$ & $\begin{array}{l}\text { To evaluate } \\
\text { effect of BLT } \\
\text { on post- } \\
\text { operative } \\
\text { circadian } \\
\text { optimization } \\
\text { and delirium }\end{array}$ & RCT (Pilot) & $\begin{array}{l}\text { ICU (surgical) } \\
\mathrm{n}=11: 5 \text { control, } 6 \\
\text { intervention } \\
\text { Middle-aged, or aged post- } \\
\text { operative esophageal cancer } \\
\text { patients, with no mental } \\
\text { disorders were randomized } \\
\text { after extubation }\end{array}$ & $\begin{array}{l}\text { BLT: } 50001 \mathrm{x} \text { from } 0730 \text { to } \\
0930 \text { for } 3 \text { of the post- } \\
\text { operative days, by a self- } \\
\text { stand or a table-top } \\
\text { illuminator } \\
\text { Control group: Usual } \\
\text { lighting: } 600-10001 \mathrm{x}\end{array}$ & $\begin{array}{l}\text { Delirium incidence (non- } \\
\text { validated Japanese } \\
\text { NEECHAM) } \\
\text { Sleep/Circadian rhythm } \\
\text { (Activity levels and rhythm } \\
\text { recorded by ankle } \\
\text { accelerometers and memory } \\
\text { heart rate recorder) }\end{array}$ & $\begin{array}{l}\text { Decreased post-operative } \\
\text { delirium rate on day } 3 \text { of the } \\
\text { BLT, but no overall significant } \\
\text { effect on delirium incidence } \\
\text { Non-significant decrease in } \\
\text { activity level during sleep }\end{array}$ \\
\hline $\begin{array}{l}\text { Ono, 2011, } \\
\text { Japan } 52\end{array}$ & $\begin{array}{l}\text { To evaluate } \\
\text { effect of BLT } \\
\text { on post- } \\
\text { operative } \\
\text { circadian } \\
\text { optimization } \\
\text { and delirium }\end{array}$ & RCT (Pilot) & $\begin{array}{l}\text { ICU ( surgical) } \\
\mathrm{n}=22: 12 \text { control, } 10 \\
\text { intervention } \\
\text { Adult post-esophagectomy } \\
\text { patients, who anticipated to } \\
\text { be extubated the day after } \\
\text { surgery, were randomized } \\
\text { after extubation }\end{array}$ & $\begin{array}{l}\text { BLT: } 2500 \text { to } 50001 x \text { from } \\
0730 \text { to } 0930 \text { for } 4 \text { days } \\
\text { (0730-0745: 25001x, 0745- } \\
\text { 0800: 40001x, 0800-0900: } \\
\text { 50001x, 0900-0915: 40001x, } \\
\text { 0915-0930 25001x), by a } \\
\text { self-standing L-shaped } \\
\text { illuminator to maintain } \\
\text { lighting in front of patient's } \\
\text { face } \\
\text { Control group: usual } \\
\text { lighting }\end{array}$ & $\begin{array}{l}\text { Delirium incidence (Validated } \\
\text { Japanese NEECHAM) } \\
\text { Sleep/Circadian rhythm } \\
\text { (Activity levels and rhythm } \\
\text { recorded by ankle } \\
\text { accelerometers and memory } \\
\text { heart rate recorder ) }\end{array}$ & $\begin{array}{l}\text { Non-significant lower rate of } \\
\text { post-operative delirium } \\
\text { Decreased amount of activity } \\
\text { during sleep on the nights of } \\
\text { days } 4 \text { and } 5\end{array}$ \\
\hline $\begin{array}{l}\text { Potharajaroe } \\
\mathrm{n}, 2018 \text {, } \\
\text { Thailand }\end{array}$ & $\begin{array}{l}\text { To evaluate } \\
\text { effect of BLT } \\
\text { on post- } \\
\text { operative } \\
\text { delirium }\end{array}$ & $\mathrm{RCT}$ & $\begin{array}{l}\text { ICU (surgical) } \\
\mathrm{n}=62: 31 \text { control, } 31 \\
\text { interventions } \\
\text { Adult patients } \geq 50 \text { years, } \\
\text { with an APACHE II Score } \geq \\
8 \text { with no current coma or } \\
\text { delirium, a life-time history } \\
\text { or current diagnosis of } \\
\text { delirium, neuro- } \\
\text { degenerative, } \\
\text { neuroinflammatory, or } \\
\text { psychiatric disease. }\end{array}$ & $\begin{array}{l}\text { BLT: Bright Light therapy, } \\
50001 \mathrm{x} \text { from } 0900 \text { to } 1100 \\
\text { for } 3 \text { days, at a distance of } \\
1.40 \mathrm{~m} \text { from the patient's } \\
\text { face } \\
\text { Control group: usual } \\
\text { lighting: 500lx }\end{array}$ & $\begin{array}{l}\text { Delirium incidence (CAM- } \\
\text { ICU) } \\
\text { Sleep (Assessing insomnia by } \\
\text { ISI) }\end{array}$ & $\begin{array}{l}\text { Decreased delirium incidence } \\
\text { Higher ISI score was } \\
\text { associated with development } \\
\text { of delirium, and BLT lowered } \\
\text { ISI scores. }\end{array}$ \\
\hline $\begin{array}{l}\text { Yang, 2012, } \\
\text { South Korea } \\
53\end{array}$ & $\begin{array}{l}\text { To determine } \\
\text { impact of BLT } \\
\text { with } \\
\text { antipsychotic }\end{array}$ & $\begin{array}{l}\text { Randomized } \\
\text { open parallel } \\
\text { group }\end{array}$ & $\begin{array}{l}\text { Consulting psychiatry } \\
\text { division of a general } \\
\text { hospital }\end{array}$ & $\begin{array}{l}\text { BLT as adjunctive treatment } \\
\text { with risperidone: } 10,000 \mathrm{~lx} \\
\text { from } 0700 \text { to } 0800 \text { for } 5\end{array}$ & $\begin{array}{l}\text { Delirium severity (DRS, } \\
\text { MDAS) }\end{array}$ & $\begin{array}{l}\text { Decreased delirium severity } \\
\text { Improve total sleep time and } \\
\text { sleep efficiency }\end{array}$ \\
\hline
\end{tabular}




\begin{tabular}{|c|c|c|c|c|c|c|}
\hline & $\begin{array}{l}\text { treatment in } \\
\text { delirious } \\
\text { patients }\end{array}$ & & $\begin{array}{l}\mathrm{n}=36 \text { (16 control, } 20 \\
\text { intervention) } \\
\\
\text { Referred hospitalized adults } \\
\text { to psychiatry division of a } \\
\text { general hospital with DRS } \geq \\
12 \text { without any other axis I } \\
\text { disorders } \\
\text { on DSM-IV or history of } \\
\text { antipsychotics or } \\
\text { benzodiazepines use before } \\
\text { screening }\end{array}$ & $\begin{array}{l}\text { days by a height-adjustable } \\
\text { light box } \\
\text { Control group: Resperidone }\end{array}$ & $\begin{array}{l}\text { Sleep (Sleep log with total } \\
\text { sleep time, efficiency, onset } \\
\text { latency, awake times questions) }\end{array}$ & \\
\hline $\begin{array}{l}\text { Chong, } \\
2013, \\
\text { Singapore }{ }^{54}\end{array}$ & $\begin{array}{l}\text { To examine } \\
\text { whether the } \\
\text { GMU program } \\
\text { improved } \\
\text { sleep, } \\
\text { cognitive, and } \\
\text { functional } \\
\text { outcomes in } \\
\text { delirious } \\
\text { patients. }\end{array}$ & $\begin{array}{l}\text { Prospective } \\
\text { cohort study }\end{array}$ & $\begin{array}{l}\text { GMU } \\
\mathrm{n}=228 \\
\text { Adult delirious patients }>65 \\
\text { years old, without coma, or } \\
\text { terminal illness, or } \\
\text { contraindications to BLT } \\
\text { (manic disorders, severe eye } \\
\text { disorders, photosensitive } \\
\text { skin disorders, or } \\
\text { photosensitizing use) }\end{array}$ & $\begin{array}{l}\text { BLT: } 2000-30001 \mathrm{x} \text { from } \\
1800 \text { to } 2200 \text { delivered by } \\
\text { ceiling lights in addition to } \\
\text { HELP protocol }\end{array}$ & $\begin{array}{l}\text { Delirium severity (CAM, DRS- } \\
\text { 98, locally validated CMMSE) } \\
\text { Sleep (Sleep log with total } \\
\text { sleep time, number of } \\
\text { awakenings, number and length } \\
\text { of sleep bouts questions) }\end{array}$ & $\begin{array}{l}\text { No significant effect on DRS } \\
\text { severity scores, but improved } \\
\text { DRS sleep-wake disturbance } \\
\text { sub-score, No significant } \\
\text { improvement on CMMSE } \\
\text { scores } \\
\text { Improved mean total sleep } \\
\text { time, and functional status } \\
\text { score during management of } \\
\text { delirium }\end{array}$ \\
\hline \multicolumn{7}{|c|}{ Environmental modification targeting both noise and light } \\
\hline $\begin{array}{l}\text { Demoule, } \\
2017, \\
\text { France }\end{array}$ & $\begin{array}{l}\text { To evaluate } \\
\text { effect of } \\
\text { earplugs and } \\
\text { eye mask on } \\
\text { sleep in ICU }\end{array}$ & RCT & $\begin{array}{l}\text { ICU (General) } \\
\mathrm{n}=43 ; 28 \text { control, } 15 \\
\text { intervention } \\
\text { Adult, non-sedated, Ramsay } \\
\begin{array}{l}\text { Sedation Scale }<3 \text {, no } \\
\text { history of sleep disorder, } \\
\text { neurological impairment, } \\
\text { encephalopathy, sepsis, ICU } \\
\text { stay }>48 \mathrm{hr}\end{array}\end{array}$ & $\begin{array}{l}\text { Earplugs and eye-masks } \\
\text { during sleep from } 2200 \text { to } \\
0800 \\
\text { Control group: No earplugs } \\
\text { or eye mask }\end{array}$ & $\begin{array}{l}\text { Delirium incidence (CAM- } \\
\text { ICU) } \\
\text { Sleep (PSG on first day of } \\
\text { study, Self-reported sleep } \\
\text { quality by simplified visual } \\
\text { analogue scale (VAS; } 10 \mathrm{~cm} \\
\text { horizontally) at discharge, and } \\
\text { by Pittsburgh Sleep Quality } \\
\text { Index at day 90) }\end{array}$ & $\begin{array}{l}\text { No effect on delirium } \\
\text { No effect on sleep proportion } \\
\text { of } \mathrm{N} 3 \text {, but improved sleep } \\
\text { quality only by increasing } \\
\text { duration of N3 stage and } \\
\text { reducing long awakenings in } \\
\text { compliant subjects. }\end{array}$ \\
\hline $\begin{array}{l}\text { McAndrew, } \\
2016, \text { USA } \\
57\end{array}$ & $\begin{array}{l}\text { To evaluate } \\
\text { effect of quiet } \\
\text { time on } \\
\text { delirium, } \\
\text { sedation level, } \\
\text { and } \\
\text { physiologic } \\
\text { measures in } \\
\text { mechanically }\end{array}$ & $\begin{array}{l}\text { Prospective } \\
\text { cohort study }\end{array}$ & $\begin{array}{l}\text { ICU (Medical) } \\
\mathrm{N}=72 \\
\text { Mechanically ventilated } \\
\text { adults until extubated }\end{array}$ & $\begin{array}{l}\text { Quiet time from } 1400 \text { to } \\
\text { 1600; Dimmed lights, } \\
\text { closed window shades, TVs } \\
\text { off, closed doors, clustered } \\
\text { care-activities }\end{array}$ & $\begin{array}{l}\text { Presence of delirium (CAM- } \\
\text { ICU) } \\
\text { Sleep (Nurse perception of } \\
\text { patient's sleep by an } \\
\text { investigator created tool with } \\
\text { uninterrupted sleep time, and } \\
\text { overall quality of sleep } \\
\text { questions) }\end{array}$ & $\begin{array}{l}\text { No significant effect on } \\
\text { delirium; however reported no } \\
\text { increase in delirium } \\
\text { Improved sleep perception } \\
\text { moderately } \\
\text { Improved respiratory rates, } \\
\text { and nursing satisfaction of } \\
\text { quiet time protocol }\end{array}$ \\
\hline
\end{tabular}




\begin{tabular}{|c|c|c|c|c|c|c|}
\hline & $\begin{array}{l}\text { ventilated } \\
\text { patients }\end{array}$ & & & & & \\
\hline $\begin{array}{l}\text { Patel, 2014, } \\
\text { UK }^{7}\end{array}$ & $\begin{array}{l}\text { To test a non- } \\
\text { pharmacologic } \\
\text { bundle with } \\
\text { environmental } \\
\text { noise and light } \\
\text { reduction } \\
\text { components on } \\
\text { delirium and } \\
\text { sleep }\end{array}$ & $\begin{array}{l}\text { Pre- post } \\
\text { Intervention }\end{array}$ & $\begin{array}{l}\text { ICU (Medical \& surgical) } \\
\mathrm{N}=338 ; 167 \text { control, } 171 \\
\text { intervention } \\
\text { Non-delirious, non-sedated } \\
\text { adults with } \geq 1 \text { ICU night, } \\
\text { and no sleep, or cognitive, } \\
\text { or neurologic disorder }\end{array}$ & $\begin{array}{l}\text { Multidisciplinary } \\
\text { intervention from } 2300 \text { to } \\
0700 \text {; Limited bedside } \\
\text { conversation, clustered care- } \\
\text { activities, minimized } \\
\text { devices noise levels, } \\
\text { dimmed lights, earplugs and } \\
\text { eye mask, patient } \\
\text { orientation, early } \\
\text { mobilization, and sedation } \\
\text { targets. } \\
\text { Control group: usual care }\end{array}$ & $\begin{array}{l}\text { Delirium incidence and } \\
\text { duration (CAM-ICU) } \\
\text { Sleep quality (RCSQ, and the } \\
\text { Sleep in Intensive Care } \\
\text { Questionnaire) } \\
\text { Level of noise } \\
\text { Level of light } \\
\text { (Two environmental meters } \\
\text { placed centrally; mean level of } \\
\text { noise reported in dB, } \\
\text { illuminance reported in lx, no } \\
\text { more information available) }\end{array}$ & $\begin{array}{l}\text { Decreased delirium incidence } \\
\text { and duration } \\
\text { Increased sleep quality, } \\
\text { decrease daytime sleepiness } \\
\text { Decreased level noise } \\
\text { Decrease level of light }\end{array}$ \\
\hline $\begin{array}{l}\text { Kamdar, } \\
2013, \text { USA } \\
58\end{array}$ & $\begin{array}{l}\text { To determine } \\
\text { impact of a } \\
\text { multi-faceted } \\
\text { quality } \\
\text { improvement } \\
\text { program on } \\
\text { ICU delirium, } \\
\text { and sleep }\end{array}$ & $\begin{array}{l}\text { Pre- post } \\
\text { Intervention }\end{array}$ & $\begin{array}{l}\text { ICU (Medical) } \\
\mathrm{n}=300 ; 122 \text { control, } 178 \\
\text { intervention } \\
\text { Adult patients with } \geq 1 \text { ICU } \\
\text { night, and discharge to an } \\
\text { inpatient ward bed or } \\
\text { pending discharge directly } \\
\text { from the ICU, without } \geq 1 \\
\text { night in another ICU during } \\
\text { the admission, any cognitive } \\
\text { disorder, or sustained } \\
\text { alcohol or drug abuse, } \\
\text { cardiac arrest during } \\
\text { admission, any other ICU } \\
\text { discharge }>96 \text { hours prior to } \\
\text { assessment }\end{array}$ & $\begin{array}{l}\text { Multi-faceted sleeping } \\
\text { promotion protocol; } 3 \\
\text { additive stages of 1) quiet } \\
\text { time, and realignment of } \\
\text { circadian rhythm, 2) } \\
\text { earplugs, eye-masks, and } \\
\text { soothing music, 3) } \\
\text { pharmacological targets to } \\
\text { reduce sedatives. } \\
\text { Control group: usual care }\end{array}$ & $\begin{array}{l}\text { Delirium incidence (CAM- } \\
\text { ICU) } \\
\text { Sleep (RCSQ) }\end{array}$ & $\begin{array}{l}\text { Decreased incidence of } \\
\text { delirium } \\
\text { No effect on quality of sleep } \\
\text { ratings }\end{array}$ \\
\hline
\end{tabular}

Abbreviations: ICU: Intensive care unit: RCT: Randomized control trial: hr: Hours: CAM-ICU: Confusion Assessment Method for theICU: LAeq: A-weighted

equivalent continuous sound level, LAFMin: A weighted, Fast time (125ms) weighted minimum sound Level, LAFMax: A weighted, Fast time (125ms) weighted maximum sound Level, LCeq: C-weighted equivalent continuous sound level, LCPeak: C-weighted peak sound level, LZPeak: Peak sound level without frequency weighting, T20: Reverbation time, C50: Clarity, RASS: Richmond Agitation and Sedation Scale, GCS: Glasgow Coma Scale/Score, DSI: delirium severity index, ICDSC: Intensive Care Delirium Screening Checklist, RCSQ: Richards-Campbell Sleep Questionnaire, dBA: A-weighted decibels, NEECHAM: Neelon and Champagne Confusion Scale, CCU: Coronary care unit, LED: Light-emitting diode, DOSS: Dutch version of the Delirium Observation Screening, CAM: Confusion Assessment Method , lx: Lux, K: Kelvin, min: minutes, BLT: Bright light therapy, ISI: Insomnia severity score, DRS: Delirium Rating Scale, DSM-IV: on Diagnostic and Statistical Manual of Mental Disorders, $4^{\text {th }}$ edition, MDAS: Memorial Delirium 
Assessment Scale, GMU: Geriatric Monitoring Unit (A specialized delirium management unit), HELP: Hospital Elder Life Program (standardized protocols to manage cognitive impairment, sleep deprivation, immobility, visual impairment, hearing impairment, and dehydration), DRS-98: Delirium rating scale-R98, CMMSE: Chinese Mini-Mental State Examination, PSG: Polysomnography,

${ }^{1}$ Outcomes of interest including delirium related outcomes, sleep quality, sound pressure levels, and light intensity levels, has listed in this table.

${ }^{2}$ Details of measured noise and light, such as devices, location, and frequency has not been discussed in detail in this table. 
Table 3. Effectiveness of Environmental Interventions on Delirium

\begin{tabular}{|c|c|c|c|c|c|c|}
\hline Intervention & Studies & $\begin{array}{l}\text { Delirium } \\
\text { incidence }\end{array}$ & $\begin{array}{l}\text { Deliriu } \\
\text { m } \\
\text { prevalen } \\
\text { ce }\end{array}$ & $\begin{array}{c}\text { Deliriu } \\
\text { m } \\
\text { duratio } \\
\text { n }\end{array}$ & $\begin{array}{c}\text { Delirium } \\
\text { severity }\end{array}$ & Statistics \\
\hline \multicolumn{7}{|c|}{ Architectural design modification } \\
\hline $\begin{array}{l}\text { Acoustic modified ICU } \\
\text { room }\end{array}$ & Johansson, $2018^{18}$ & -- & $\mathrm{NA}^{1}$ & -- & -- & No analysis done due to small sample size \\
\hline $\begin{array}{l}\text { Private room with less } \\
\text { noise and more light } \\
\text { exposure }\end{array}$ & Zaal, $2013^{47}$ & $\mathrm{NSE}^{2}$ & -- & $\downarrow^{3}$ & NSE & $\begin{array}{l}\text { Delirium incidence: } 51 \% \text { control } 45 \% \text { intervention, (OR } 0.6,95 \% \text { CI } 0.3- \\
1.6, p=0.53 \text { ) } \\
\text { Delirium duration: Decreased number of days with delirium by } 0.4(95 \% \mathrm{CI} \\
0.1-0.7, \mathrm{p}=0.005) \\
\text { Delirium severity: } \mathrm{DSI} \text { score per day with delirium, mean (SD): } 2.3 \pm 0.7 \\
\text { control, } 2.5 \pm 0.8 \text { intervention, } \mathrm{p}=0.34\end{array}$ \\
\hline \multicolumn{7}{|c|}{ Noise modification interventions } \\
\hline $\begin{array}{l}\text { Sound reduction } \\
\text { protocol (Behavioral } \\
\text { strategies and earplugs) }\end{array}$ & van de Pol, $2017^{14}$ & $\downarrow$ & -- & -- & -- & Delirium incidence decreased by $3.7 \%$ per time period $(p=0.02)$ \\
\hline Earplugs & $\begin{array}{l}\text { Van Rompaey, } 2012 \\
48\end{array}$ & $\begin{array}{l}\text { NSE, } \\
\text { Decreased } \\
\text { risk of } \\
\text { confusion }\end{array}$ & -- & -- & -- & $\begin{array}{l}\text { Delirium incidence: } 20 \% \text { control, } 19 \% \text { intervention } \\
\text { Risk of confusion/ early delirium: decreased by } 53 \% \text { (HR .0.47, } 95 \% \text { CI } \\
0.27 \text { to } 0.82 \text { ) } \\
\text { Median NEECHAM score: } 24 \text { (829) control } 26 \text { (5-29) intervention (Mann- } \\
\text { Whitney U, } p=0.04 \text { ) } \\
\text { Time to cognitive disturbance onset: Increased, } \mathrm{p}=0.006\end{array}$ \\
\hline \multicolumn{7}{|c|}{ Light modification interventions } \\
\hline \multirow{3}{*}{$\begin{array}{l}\text { Artificial dynamic/ } \\
\text { circadian lighting }\end{array}$} & Estrup, $2018^{15}$ & NSE & -- & -- & -- & $\begin{array}{l}\text { Delirium incidence: } 28 \% \text { control, } 30 \% \text { intervention, (OR } 1.14 ; 95 \% \text { CI } 0.55- \\
2.37 ; p=0.73 \text { ) }\end{array}$ \\
\hline & Pustjens, $2019^{49}$ & NSE & -- & -- & -- & $\begin{array}{l}\text { Delirium incidence, } \mathrm{n}(\%): 19 / 379(5.0) \text { control } 20 / 369(5.4) \text { intervention, } \mathrm{p} \\
=0.802\end{array}$ \\
\hline & Simons, $2016^{50}$ & NSE & -- & NSE & -- & $\begin{array}{l}\text { Delirium incidence, } \mathrm{n}(\%): 123 / 373(33) \text { control } 137 / 361 \text { (38) intervention, } \\
\text { (OR 1.24, } 95 \% \text { CI 0.92-1.68, } \mathrm{p}=0.16) \\
\text { Delirium duration (hours): } 2(1-5) \text { control, } 2(2-5) \text { intervention, } \mathrm{p}=0.87\end{array}$ \\
\hline \multirow[t]{4}{*}{ Bright light therapy } & Taguchi, $2007^{51}$ & $\begin{array}{l}\text { NSE, } \\
\text { Decreased } \\
\text { delirium } \\
\text { scores on } \\
\text { day } 3 \text { of } \\
\text { BLT } \\
\end{array}$ & -- & -- & -- & $\begin{array}{l}\text { Delirium incidence: } 40 \% \text { control, } 16 \% \text { intervention, } p=0.42 \text { by Fisher's } \\
\text { exact probability test. There was a significant difference in NEECHAM } \\
\text { delirium score between the two groups on the morning of day } 3 \text { of BLT by } \\
\text { the Mann-Whitney U-test }(p=0.014)\end{array}$ \\
\hline & Ono, $2011^{52}$ & NSE & -- & -- & -- & Delirium incidence, $n(\%): 5 / 12$ (42) control, $1 / 10(10)$ intervention, $p>0.05$ \\
\hline & $\begin{array}{l}\text { Potharajaroen, } 2018 \\
55\end{array}$ & $\downarrow$ & -- & -- & -- & $\begin{array}{l}\text { Delirium incidence, } \mathrm{n}(\%): 11 / 31(35) \text { control } 2 / 31(6) \text { intervention, }(\mathrm{OR} \\
0.12,95 \% \text { CI } 0.03-0.54, \mathrm{p}=0.005)\end{array}$ \\
\hline & Yang, $2012^{53}$ & -- & -- & -- & $\downarrow$ & $\begin{array}{l}\text { DRS score: decreased in study group }(\mathrm{F}=2.87, \mathrm{p}=0.025) \\
\text { MDAS score: Not significantly different between the two groups }\end{array}$ \\
\hline
\end{tabular}




\begin{tabular}{|c|c|c|c|c|c|c|}
\hline & Chong, $2013^{54}$ & -- & -- & $\mid--$ & $\begin{array}{l}\text { NSE, } \\
\text { Improved } \\
\text { functional } \\
\text { and sleep } \\
\text { outcomes }\end{array}$ & $\begin{array}{l}\text { DRS severity score: decreased by } 6.2 \pm 6.3 \text { ( } 22.5 \pm 5.8 \text { versus } 14.6 \pm 6.1 \text { in } \\
\text { initial versus discharge DRS, } p>0.05)\end{array}$ \\
\hline \multicolumn{7}{|c|}{ Environmental modification targeting both noise and light } \\
\hline Earplugs \& eye mask & Demoule, $2017^{56}$ & NSE & -- & -- & -- & Delirium incidence, $n(\%): 2 / 22(6)$ control 2/23 (7) intervention, $p=1$ \\
\hline Quiet time & McAndrew, $2016^{57}$ & -- & NSE & -- & -- & No significant effect on delirium scores $(\mathrm{p}=0.648)$ \\
\hline \multirow{2}{*}{$\begin{array}{l}\text { Multi-component sleep } \\
\text { promotion protocol }\end{array}$} & Patel, $2014^{7}$ & $\downarrow$ & -- & $\downarrow$ & -- & $\begin{array}{l}\text { Delirium incidence, } \mathrm{n}(\%): 55 / 167 \text { (33) control 24/171 (14) intervention, (OR } \\
0.33,95 \% \text { CI } 0.19-0.57, \mathrm{p}<0.001 \text { ) } \\
\text { Delirium duration (length of time spent delirious), mean } \pm \mathrm{SD}: 3.4 \pm 1.4 \\
\text { control, } 1.2 \pm 0.9 \text { intervention, } \mathrm{p}=0.021 \\
\text { Improved sleep efficiency index was associated with a lower risk of } \\
\text { developing delirium (OR 0.90, 95\% CI 0.84-0.97) }\end{array}$ \\
\hline & Kamdar, $2013^{58}$ & $\downarrow$ & -- & $\mid--$ & -- & $\begin{array}{l}\text { Incidence of delirium/coma, } \mathrm{n}(\%): 76 / 110(69) \text { control, } 86 / 175 \text { (49) } \\
\text { intervention, (OR 0.46; 95\% CI 0.23-0.89, } \mathrm{p}=0.02 \text { ) } \\
\text { Daily delirium/coma-free status, } \mathrm{n}(\%): 272 / 634(43) \text { control, } 399 / 826 \text { (48) } \\
\text { intervention, (OR 1.64, 95\% CI, } 1.04-2.58, \mathrm{p}=0.03 \text { ) }\end{array}$ \\
\hline
\end{tabular}

Abbreviations: OR: Odds Ratio, CI: Confidence Interval, DSI: Delirium Severity Index, SD: Standard Deviation, HR: Hazard Ratio, NEECHAM: Neelon and Champagne Confusion Scale, BLT: Bright light therapy, DRS: Delirium Rating Scale, MDAS: Memorial Delirium

${ }^{1}$ No statistical analysis was done

${ }^{2}$ No significant effect

${ }^{3}$ Decreased 